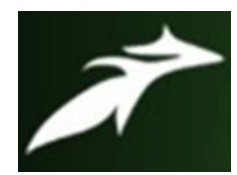

Amit Rastogi et al, International Journal of Advances in Agricultural Science \& Technology,

Vol.8 Issue.12, December-2021, pg. 39-74

ISSN: 2348-1358

Impact Factor: 6.057

NAAS Rating: 3.77

\title{
Review on Microbial Sources, Production, Purification and Potential Industrial Applications of Laccases
}

\author{
Amit Rastogi ${ }^{1}$; Rajesh Singh ${ }^{2}$; Ahmed Barhoum ${ }^{3,4}$ \\ ${ }^{1}$ Research Scholar, Shri Venkateshwara University, Gajraula, U.P., INDIA \\ ${ }^{2}$ Director Research and Planning, Shri Venkateshwara University, Gajraula, U.P., INDIA \\ ${ }^{3}$ Associate Professor, Chemistry Department, Faculty of Science, Helwan University, Cairo, Egypt \\ ${ }^{4}$ School of Chemical Sciences, Dublin City University, Dublin, IRELAND \\ Corresponding Author: amitrastogi.editor1986@gmail.com
}

DOI: 10.47856/ijaast.2021.v08i12.004

\begin{abstract}
Laccase (EC 1.10.3.2) is a multicopper blue oxidase which are involved in the oxidation of a broad range of organic substrates, including phenols, polyphenols, anilines, and even certain inorganic compounds by a one-electron transfer mechanism. Laccases are widely distributed in bacteria, fungai, insects and higher plants. There are mainly two production techniques for cultivation of laccase such as submersed fermentation and solidstate fermentation. This paper briefly discuss the effect of carbon source, effect of nitrogen source, effect of inducers, effects of surfactants, effect of agitator, influence of metal ions and use of agro-industrial waste in production medium. The paper also discussed the purification techniques such as ammonium sulphate precipitation for extraction purpose followed by dialysis and ion-exchange chromatography as well characterization techniques. Laccases are known to show application ranging from pharmaceutical industries to textile sector as well as in biosensor development.
\end{abstract}

\section{INTRODUCTION}

In recent years, investigations on enzymes have gained a great interest of industrial scientists due to their wide range of applications; laccases are one among them which are widely present in nature. Laccases are the oldest and most studied enzymatic systems. These enzymes contain 15-30\% carbohydrate and have a molecule mass of 60-90 kDa (Shraddha et al., 2011). Laccase (EC 1.10.3.2) is a multicopper blue oxidase which are involved in the oxidation of a broad range of organic substrates, including phenols, polyphenols, anilines, and even certain inorganic compounds by a one-electron transfer mechanism (Hakulinen et al., 2015). Yoshida et al. first discovered laccases in 1883 in an observation where latex from the Japanese lacquer tree (Rhus vernicifera) hardened in the presence of air (Call and 


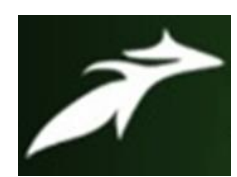

Amit Rastogi et al, International Journal of Advances in Agricultural Science \& Technology, Vol.8 Issue.12, December-2021, pg. 39-74

ISSN: 2348-1358

Impact Factor: 6.057

NAAS Rating: 3.77

Mücke, 1997; Gianfreda et al., 1999). Laccases are regarded as multinuclear coppercontaining glycoproteins which belong to the family of enzymes known as oxidases, more specifically "blue" oxidases (Yaropolov et al., 1994), and polyphenol oxidases (Gianfreda et $a l ., 1999)$. Laccases are considered one of six enzyme classes which are capable of reducing dioxygen to water, five of which belong to the multicopper oxidase family (the only enzyme not in this class being cytochrome-c oxidase, a heme/copper containing enzyme). Laccase is a polyphenol oxidase, which can oxidize a phenolic substrate that in turn can initiate a polymerization reaction (Gianfreda et al., 1999, Kumar et al., 2011). Laccases from various sources vary greatly in account to their degree of glycosylation, molecular weight and kinetic properties (Yaropolov et al., 1994). Laccases are widely distributed in bacteria, fungai, insects and higher plants. In fungai, laccases are widely distributed in Ascomycetes, Deuteromycetes, and Basidiomycetes, as well as found abundantly in many white rot fungi that are involved in lignin metabolism In plants, laccases are found in cabbages, turnip, potatoes, pears, apples, and other vegetables (Shraddha et al., 2011). Recently, bacterial laccase are gaining the interest of researchers for industrial application in comparison to fungal laccase due to their remarkable features such as work in a broad range of temperature and $\mathrm{pH}$ as well as due to their stability against various inhibitory agents. Also bacterial laccases are cost effective, showing broad substrate specificity with less production time as compared to fungal laccases (Guan et al., 2015). There are mainly two production techniques for cultivation of laccase such as submersed fermentation and solid- state fermentation (Chauhan et al., 2017). For purification purposes generally extraction and dialysis are performed followed by column or ion-exchange chromatography as well as characterization of laccase is done through SDS-PAGE (Shraddha et al., 2011). Laccases are known to show application ranging from pharmaceutical industries to textile sector as well as in biosensor development (Singh et al., 2020). The goal and scientific contribution of this paper is to provide scientific knowledge to the enzyme researchers about microbial sources of laccases, mode of action of laccases, production techniques of laccases, purification techniques of laccases and application of laccases from textile sectors to pharmaceutical sector as well fabrication of biosensors. This paper also briefly discuss the effect of carbon source, effect of nitrogen source, effect of inducers, effects of surfactants, effect of agitator, influence of metal ions and use of agro-industrial waste in production medium. This paper also briefly discusses the purification techniques such as ammonium sulphate precipitation for extraction purpose followed by dialysis and ion-exchange chromatography as well characterization techniques. 


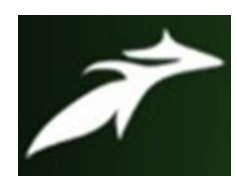

Amit Rastogi et al, International Journal of Advances in Agricultural Science \& Technology, Vol.8 Issue.12, December-2021, pg. 39-74

ISSN: 2348-1358

Impact Factor: 6.057

NAAS Rating: 3.77

\section{LACCASES AS METALLO-ENZYMES}

Laccases are the enzymes which contain four copper(II) atoms per molecule that are essential for its catalytic activity (Ragusa et al., 2002). These four copper(II) atoms can be classified into three groups, type-1, type-2, and type-3 pair (Gianfreda et al., 1999, Ragusa et al., 2002) and are defined in terms of their spectroscopic properties and their electronic potential as determined by and their electron paramagnetic resonance (EPR) pattern (Gianfreda et al., 1999; Ragusa et al., 2002). Type-1 and type-2 copper atoms act strong electronic absorption, and have well defined EPR spectra, while the type-3 pair of copper(II) atoms are strongly coupled and are EPR silent (Ragusa et al., 2002), which may be activated by strong anion binding (Gianfreda et al., 1999). Laccases generally display two absorption peaks when subjected to a UV-Vis wavelength scan, a strong absorbance is visible at $600 \mathrm{~nm}$ and is associated with the type- 1 copper, while a shoulder at $330 \mathrm{~nm}$ is indicative of the type- 3 pair of copper atoms. The occurrences of laccases that do not display this characteristic spectrum have been reported. A "white" laccase was said to be isolated from Pleurotus ostreatus (Palmieri et al., 1997), while (Leontievsky et al. 1997) reported the presence of "yellow" laccases. The loss of the absorption peak at $600 \mathrm{~nm}$ of the "white" laccase was associated with the presence of only a single copper atom in the metal cluster, the other three atoms being replaced by two zinc and one iron atom (Palmieri et al., 1997). (Leontievsky et al. 1997) associate the loss of this peak in the case of "yellow" laccases to copper atoms being present in their reduced state.

\section{Source of microbial Laccase}

In bacteria laccase is present intracellularly and as periplasmic protoplast (Claus, 2003, Arora and Sharma, 2010, Shekher et al., 2011). The first bacterial laccase was discovered in the plant root associated bacterium, Azospirillum lipoferum (Givaudan et al., 1993, Sharma et al., 2007, Sharma and Kuhad, 2008), where it was exhibited to be involved in melanin formation (Faure et al., 1994, Sharma and Kuhad, 2008). It also plays a role in cell pigmentation, oxidation of phenolic compounds (Faure et al., 1994, 1995) and/or electron transport (Alexandre et al., 1999).

Laccase was also discovered in bacteria including Bacillus subtilis, Bordetella compestris, Caulobacter crescentus, Escherichia coli, Mycobacterium tuberculosum, Pseudomonas syringae, Pseudomonas aeruginosa, and Yersinia pestis , S. laven dulae, S. cyaneus, Marinomonasn mediterranea, Aquifex aceolicus, Bacillus sp., Bacillus halodurans, Leptothrix discophora, Oceano bacillusiheyensis (cotA), Alpha proteobacterium SD21, Gama-proteobacterium JB, Pseudomonas fluorescens GB-1, Pseudomonas maltophila, Pseudomonas putida GB1 (cumA), Pseudomonas aerophilum (pae1888), Streptomyces antibioticus, Streptomyces griseus (epoA), Thermus thermophilus HB27, Xanthomonas 


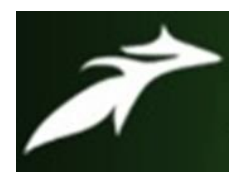

Amit Rastogi et al, International Journal of Advances in Agricultural Science \& Technology, Vol.8 Issue.12, December-2021, pg. 39-74

ISSN: 2348-1358

Impact Factor: 6.057

NAAS Rating: 3.77

campesteris (copA) and Streptomyces psammoticus MTCC 7334 etc. (Alexandre and Zhulin, 2000, Enguita et al., 2003, Arora and Sharma, 2010). Recently, laccase has been discovered in Stenotrophomonas maltophilia strain. This strain was utilized to degrade synthetic dyes (Galai et al., 2011; Arora and Sharma, 2010). Laccase also discovered in marine bacterium Marinomonas mediterranea, but there was no functional role of this enzyme assigned (Amat et al., 2001; Sharma and Kuhad, 2008).

Different fungi produce laccase over a wide range of taxa. Groups of fungi including deuteromycetes, ascomycetes (Aisemberg et al., 1989) as well as basidiomycetes are the known producers of laccase (Sadhasivam et al., 2008). All of them, basidiomycetes are recognized as efficient laccase producers, especially white rot fungi (Revankar and lele, 2006; Sadhasivam et al., 2008).

Laccase production does not occur in lower fungi including Zygomycetes and Chytridiomycetes. However, detailed investigation of these groups has not been reported. (Arora and Sharma, 2010). Trametes versicolor, Chaetomium thermophilum and Pleurotus eryngii are reported to be efficient producers of laccase. Studies reported Trichoderma species, including $T$. harzianum has shown the ability to produce polyphenol oxidases(Kiiskinen et al., 2004, Sadhasivam et al., 2008). Laccase has been produced by many species of soft, white rot fungi, geophilous saprophytic fungi. Studies reported that laccase production occurs in many edible mushrooms including the oyster mushroom Pleurotus ostreatus, the rice mushroom Lentinula edodes and champignon Agaricus bisporus. Other laccase producers of wood-rotting fungi are T. hirsuta (C. hirsutus), T. villosa, T. gallica, Cerrena maxima, Lentinus tigrinus, T. ochracea, Pleurotus eryngii, Trametes (Coriolus) versicolor, Coriolopsis polyzona, etc. (Morozova et al., 2007). Different sources of laccases with their applications are given in figure 1. 


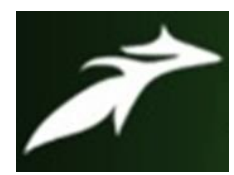

Amit Rastogi et al, International Journal of Advances in Agricultural Science \& Technology, Vol.8 Issue.12, December-2021, pg. 39-74

ISSN: 2348-1358

Impact Factor: 6.057

NAAS Rating: 3.77

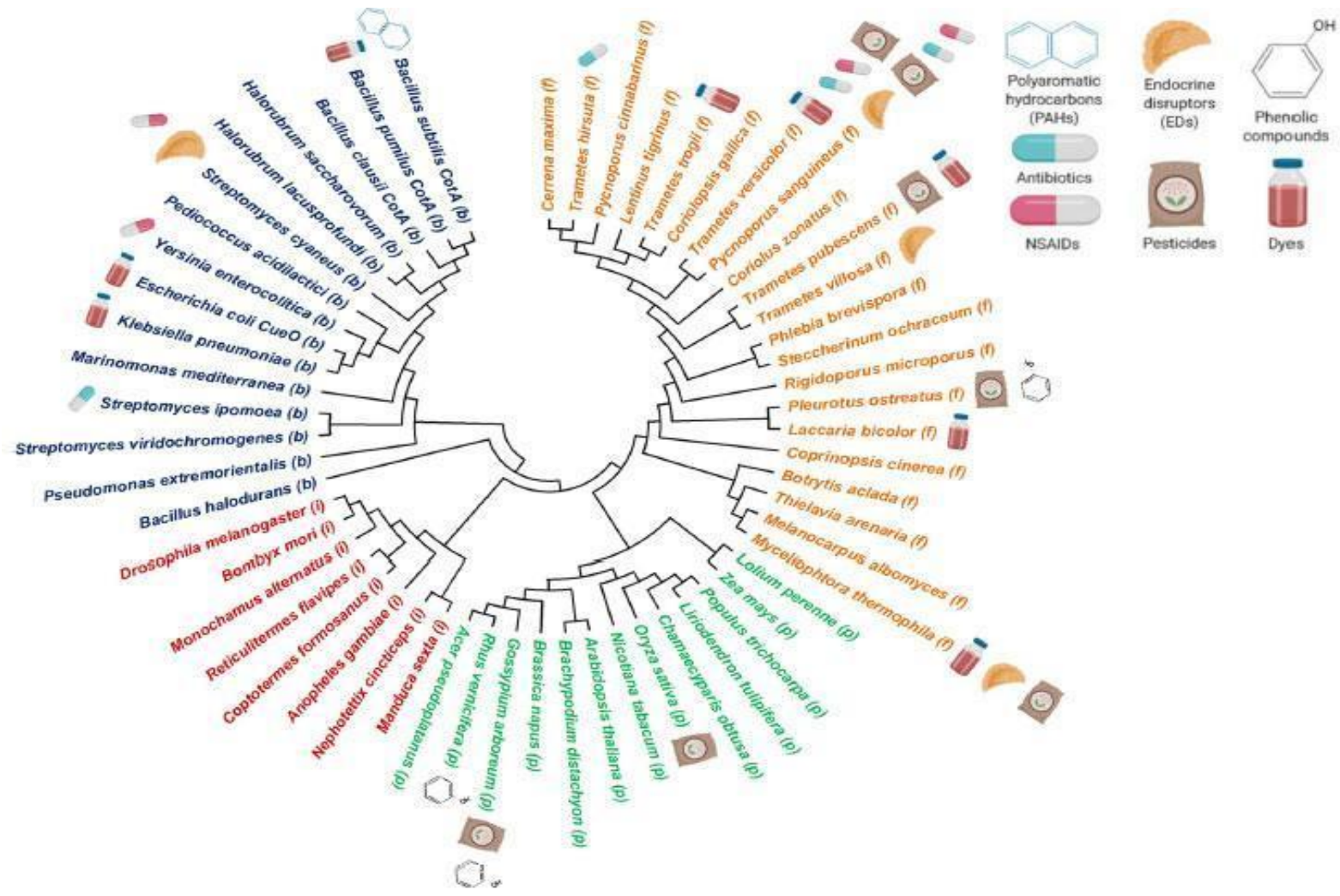

Figure1: Different sources of laccases with their applications.

Laccases from basidiomycetes (white rot fungi) are studied completely (not least also with respect to laccase-mediator interaction), and many of them have been purified and characterized on the protein and gene level (Liers et al., 2007).

Laccases are a diverse group of multi-copper proteins with broad substrate range, originally discovered in the exudates of Rhus vernicifera, the Japanese lacquer tree and subsequently demonstrated as a fungal enzyme as well (Sharma and Kuhad, 2008). Laccase also reported in plants including lacquer, mango, mung bean, peach, pine, prune, and sycamore (Arora and Sharma, 2010). Techniques are also being developed to express laccase in the crop plants. Recently, laccase has been expressed in the embryo of maize (Zea mays) seeds (Bailey et al., 2004; Arora and Sharma, 2010).

Insect laccases are long amino-terminal sequences which are characterized by a unique domain consisting of many conserved cysteine, aromatic, and charged residues. Laccases are characterized in different insects including Bombyx, Calliphora, Diploptera, Drosophila, Lucilia, Manduca, Musca, Orycetes, Papilio, Phormia, Rhodnius, Sarcophaga, Schistocerca, and Tenebrio (Arora and Sharma, 2010). Studies reported that insect laccases are involved in 


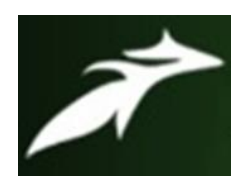

Amit Rastogi et al, International Journal of Advances in Agricultural Science \& Technology, Vol.8 Issue.12, December-2021, pg. 39-74

ISSN: 2348-1358

Impact Factor: 6.057

NAAS Rating: 3.77

cuticle sclerotization (Dittmer et al., 2004; Sharma and Kuhad, 2008). Recently, two isoforms of laccase gene have been reported to catalyse larval, pupal, and adult cuticle tanning in Tribolium castaneum (Arakane et al., 2005, Sharma and Kuhad, 2008).

Studies reported laccases are found in the several plants including Cabbages, Turnips, Beets, Apples, Asparagus, Potatoes, Pears, Peach, Sycamore, tobacco and various other vegetables. Recently, laccases are reported to be expressed in the embryo of maize (Zea mays) seeds (Bailey et al., 2004, Arora and Sharma, 2010).

\section{MODE OF ACTION OF THE LACCASE ENZYME}

Laccases have four copper atoms which are classified into three types, termed $\mathrm{Cu}$ T1 (where the reducing substrate binds) and tri-nuclear copper cluster T2/T3 (where oxygen binds and is reduced to water). These three types of copper can be classified by using UV/visible and Electronic Paramagnetic Resonance (EPR) spectroscopy. Type $1 \mathrm{Cu}$ in oxidized resting state is mainly produce blue colour of the protein at an absorbance of approximately $610 \mathrm{~nm}$ and is EPR detectable whereas Type $2 \mathrm{Cu}$ does not produce colour but is EPR detectable and Type 3 $\mathrm{Cu}$ atoms made up of a pair of $\mathrm{Cu}$ atoms in a binuclear conformation which gives a weak absorbance in the near UV region but not detectable EPR signal (Thurston, 1994, Shraddha et al., 2011).

The Type 2 and Type 3 copper sites are near together to make a trinuclear centre which are involved in the catalytic mechanism of the laccase. T2/T3 tri-nuclear site is involved in the reduction of molecular oxygen which occurs by accepting electrons from $\mathrm{T} 1$ site. Spectroscopic and DFT studies confirms the clarification of the nature coordination of the copper sites in laccase (Quintanar et al., 2005) which showed that the T2 copper site is coordinated to two His-N and one oxygen atom as $\mathrm{OH}-$ while each of the T3 coppers coordinates to three His residues. Moreover, both T2 and T3 copper sites have open coordination positions towards the center of the trinuclear cluster with the negative protein pocket (four conserved Asp/Glu residues). Reduction of oxygen occurs via the formation bound oxygen intermediates (Zoppellaro et al., 2000). Laccase catalysis involved three major steps. The Type $1 \mathrm{Cu}$ can be reduced by a reducing substrate, which accordingly is oxidized. The electron is then transferred internally from Type $1 \mathrm{Cu}$ to a tri-nuclear cluster which is made up of the Type 2 and Type $3 \mathrm{Cu}$ atoms. The $\mathrm{O}_{2}$ molecule binds to the tri-nuclear cluster for asymmetric activation and it is known that the $\mathrm{O}_{2}$ binding pocket appears to restrict the contact of oxidizing agents other than $\mathrm{O}_{2} \cdot \mathrm{H}_{2} \mathrm{O}_{2}$ is not detected outside of laccase during laccase catalysis which indicates that a four electron reduction of $\mathrm{O}_{2}$ to water is occurring (Gianfreda et al., 1999). 


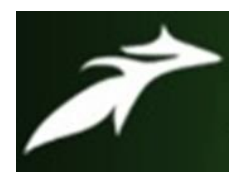

Amit Rastogi et al, International Journal of Advances in Agricultural Science \& Technology, Vol.8 Issue.12, December-2021, pg. 39-74

ISSN: 2348-1358

Impact Factor: 6.057

NAAS Rating: 3.77

Laccase oxidized substrate which is a one-electron reaction that generates a free radical. The oxidation of lignin occurs by phenoxy radical that leads to either oxidation at $\mathrm{C} \alpha$-carbon or cleavage of bond between $\mathrm{C} \alpha$-carbon and $\mathrm{C} \beta$-carbon. This oxidation produces an oxygencentered free radical, which can be converted in a second enzyme-catalysed reaction to form quinone. The quinone and the free radicals can undergo polymerization (Thurston, 1994). The presence of electron withdrawing substituents at phenoxy groups and bulky groups are more difficult to be oxidised. Laccase catalysed oxidation of phenols, anilines and benzene correlates with the redox potential difference between laccase's T1 copper site and the substrate $(\mathrm{Xu}, 1996)$.

Studies reported laccases are involved in the oxidation of non-phenolic and lignin in the presence of mediators -2,2'-azinobis-(3-ethylbenzthiazoline-6- sulfonate) (ABTS), 1hydroxybenzotrizole (HBT) and 3 hydroxyanthranilic acid (Bourbonnais et al., 1995). As oxygen uptake by laccase in the presence of ABTS is faster than in case of HBT. ABTSmediated oxidation of nonphenolic substrates occurs with the aid of electron transfer mechanism which includes the formation of $\mathrm{ABTS}^{++}$. Mechanism of laccase action for both phenolic and non-phenolic substrates is given in figure 2 .
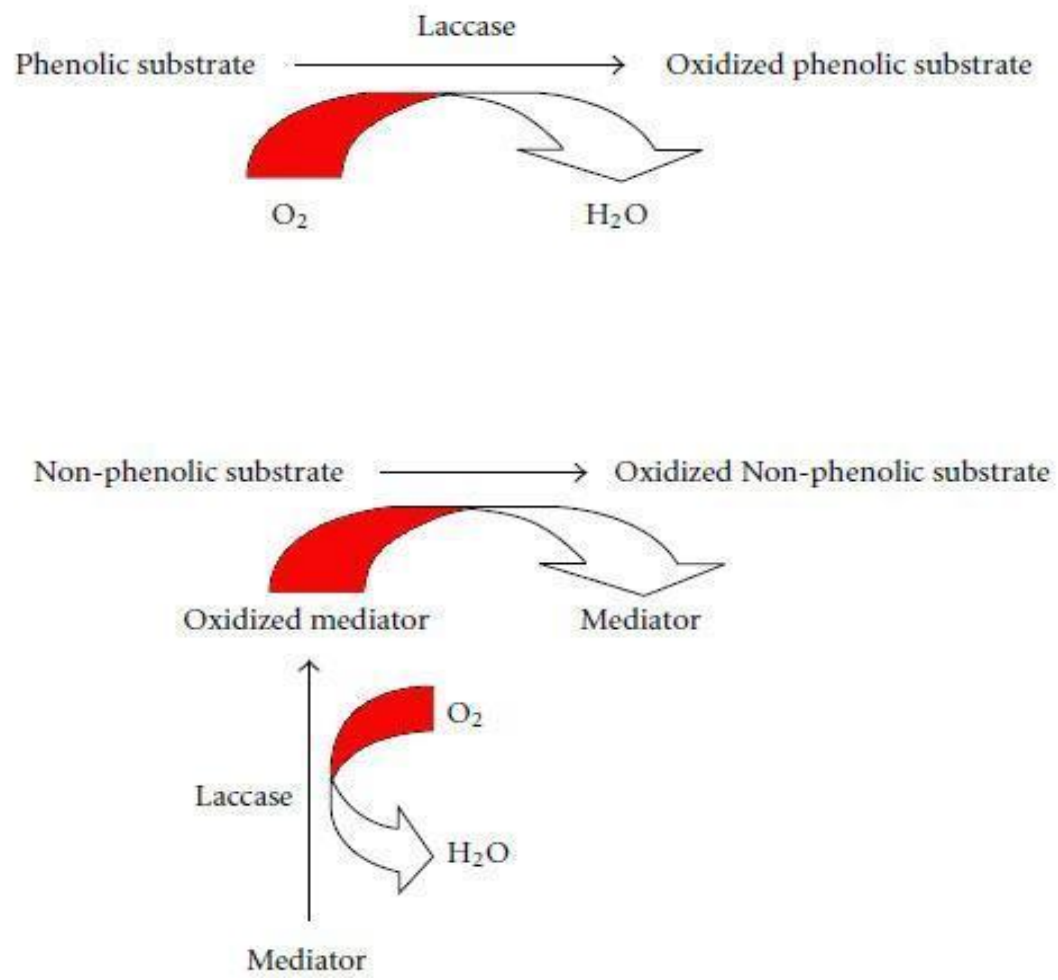

Figure 2: Mechanism of laccase action for both phenolic and nonphenolic substrates. 


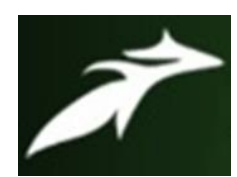

Amit Rastogi et al, International Journal of Advances in Agricultural Science \& Technology, Vol.8 Issue.12, December-2021, pg. 39-74

ISSN: 2348-1358

Impact Factor: 6.057

NAAS Rating: 3.77

\section{Laccase mediator system}

Laccases are involved in the oxidation of only phenolic fragments of lignin. This is due to the polymer nature of lignin and lower redox potential of laccase. Small natural low molecular weight compounds with higher redox potential than laccase $(>900 \mathrm{mV})$ are called mediators and may be utilized to oxidize the non-phenolic part of lignin. In recent years the discovery of new and efficient synthetic mediators extended the laccase catalysis towards xenobiotic substrates. A mediator is a small molecule that acts as a sort of electron shuttle: once it is oxidized by the enzyme generating a strongly oxidizing intermediate, the co-mediator (oxidized mediator), it diffuses away from the enzymatic pocket and in turn oxidizes any substrate that, due to its size could not directly enter into the active site. Moreover, the use of mediators allows the oxidation of polymers via side-stepping the inherent steric hindrance problems (enzyme and polymer do not have to interact in a direct manner) (Du et al., 2013).

Alternatively, the oxidized mediator could rely on an oxidation mechanism which is not available to the enzyme, thus extending the range of substrates accessible to it. It is therefore of primary importance to understand the nature of the reaction mechanism operating in the oxidation of a substrate by the oxidized mediator species derived from the corresponding mediator investigated. In the laccase-dependent oxidation of non-phenolic substrates, previous evidence suggests an Electron-Transfer (ET) mechanism with mediator ABTS, towards substrates having a low oxidation potential. Alternatively, a radical hydrogen atom transfer (HAT) route may operate with $\mathrm{N}-\mathrm{OH}$ type mediators, if weak $\mathrm{C}-\mathrm{H}$ bonds are present in the substrate. Catalytic cycle of a laccase mediator oxidation system is given in figure 3 .

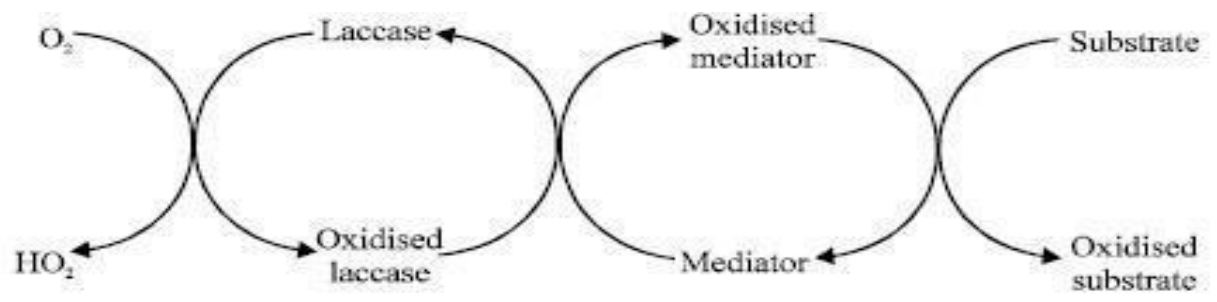

Figure 3: Catalytic cycle of a laccase mediator oxidation system

More than 100 mediator compounds have been reported but the most commonly utilized mediators are the ABTS and the triazole 1-hydroxybenzotriazole (HBT). Various laccases readily oxidize ABTS, by free radicals, to the cation radical ABTS+ and the concentration of the intensely colored, green-blue cation radical can be correlated to the enzyme activity $\left(\varepsilon 418=36000 \mathrm{M}^{-1} \mathrm{~cm}^{-1}\right)$. Cation radicals represent an intermediate oxidation step in the redox cycle of azines and upon extended oxidation and abstraction of the second electron, the corresponding dications can be obtained. The redox potentials of ABTS $+\bullet$ and ABTS2+ were 


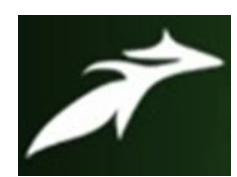

Amit Rastogi et al, International Journal of Advances in Agricultural Science \& Technology, Vol.8 Issue.12, December-2021, pg. 39-74

ISSN: 2348-1358

Impact Factor: 6.057

NAAS Rating: 3.77

assessed as 0.680 and $1.09 \mathrm{~V}$ respectively. HBT belongs to the $N$-heterocyclic compounds containing $\mathrm{N}-\mathrm{OH}$ groups mediators. Consuming oxygen HBT is converted by the enzyme into the active intermediate, which is oxidized to a reactive radical (R-NO.) and HBT redox potential has been estimated as 1.1-1.2 V. Mediated laccase catalysis utilized in a wide range of applications including pulp delignification, textile dye bleaching, polycyclic aromatic hydrocarbon degradation, pesticide or insecticide degradation and organic synthesis. In the pulp and paper industry, novel enzymatic bleaching technologies are attracting increasing attention because of concerns regarding the environmental impact of the chlorine-based oxidants currently being used in delignification or bleaching. However, synthetic mediators are toxic, expensive and generally at concentrations above $1 \mathrm{mM}$ inactivate the laccase. Novel approaches to overcome this complication are coming up (from searching for natural mediators such as $p$-coumaric acid, 4-hidroxybenzoic acid, syringaldehyde etc.) to the directed evolution of laccases, as referred by (Kunamneni et al., 2007). (Jin et al., 2016) demonstrated the application of Laccase-mediator System (LMS) for the Laccase-catalyzed Pesticide Degradation.

\section{PRODUCTION OF LACCASE}

Fermentation techniques are generally utilized for the production of laccase. These techniques are of two types: Solid-State Fermentation (SSF) and submerged fermentation $(\mathrm{SmF})$. The main difference between these two techniques is the presence of free flowing liquid present in the system mainly in the submerged fermentation. In solid state fermentation the growth of microorganisms occur on solid materials in the absence or near-absence of free flowing water, whereas in submerged fermentation the microorganism's growth occurs on a continuous liquid phase. There are many reports to the field of laccase production with the help of submerged fermentation using different microorganisms, at different scales and with the possible utilization of immobilization supports and the addition of inducers. Trametes genus is actively involved in the production of laccase which includes T. pubescens (Galhaup et al., 2002), T. versicolor (Font et al., 2003, Tavares et al., 2005) and T. hirsuta (Roriz et al., 2009). Bacillus subtilis MTCC 2414 has been reported to produce extracellular laccase by solid state fermentation using agro residues as a potential substrate (Narayanan et al., 2015).

\section{Submerged fermentation}

Laccase producing microorganisms works under the laccase production medium to produce the laccase. This production medium has been optimized by the researchers to get optimum production of the enzyme. Different components of the media such as carbon source, nitrogen source and inducers etc. are optimized to get the best production of enzyme. 


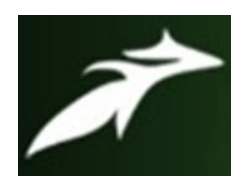

Amit Rastogi et al, International Journal of Advances in Agricultural Science \& Technology, Vol.8 Issue.12, December-2021, pg. 39-74

ISSN: 2348-1358

Impact Factor: 6.057

NAAS Rating: 3.77

Effect of carbon source: Production of ligninolytic enzymes mainly depends on carbon sources of the medium. (Jhadav et al., 2009) utilized P. chrysosporium as a source of laccase to optimize the laccase production. Laccase production and its activity was measured using a production medium containing different carbon sources.

Laccase production time was optimized using medium containing glucose and guaiacol. 10th day was the standard time for the production of laccase. The laccase activity was obtained high in medium containing rice and maize bran than glucose as carbon source. But the activity reported in medium containing the glucose and an inducer guaiacol was very high activity. This study suggested that utilization of inducers in combination with alternative carbon sources including rice and maize bran can further increase the production of enzymes. (D’Souza-Ticlo et al., 2006) reported fructose as carbon sources produce maximum laccase activity.

Effect of nitrogen source: (D'Souza-Ticlo et al., 2006) studied the effect of different type of nitrogen source which are involved in the laccase production. They utilized $\mathrm{KNO}_{3}$, glutamic acid, glycine, corn steep liquor and beef extract as nitrogen sources under stationary conditions. They oxygenated the cultures every third day with pure oxygen for $1 \mathrm{~min}$ using tygon tubing and pasteur pipettes under sterile conditions. They obtained best results when glutamic acid was used as a nitrogen source.

Effect of inducers: Scientists reported the laccase production with utilizing inducers in many researches which was yielding very good results. (Tavares et al., 2005) reported the induced laccase production using $T$. versicolor culture with the help of inducers such as $\mathrm{CuSO}_{4}$ and 2, 5 xylidine.

The experimental support for potential application of laccases on pulp and paper, textile industry and bioremediation was provided by the work of (Xavier et al., 2007), which gave a detailed report on the potential of paper and pulp industrial effluents to induce production of laccase in T. versicolor. Different concentrations of inducers in two different media namely TDM (Tramatese Defined Medium) and TaK medium were studied along with suppression of carbon source. The study concluded that inducers alone, in combination with suppression of carbon source had different effects on laccase production.

(Galai et al., 2009) reported enhanced laccase activity when Triton-X-100 (0.1\% v/v) was used in reaction mixture. The enzymes had improved catalytic efficiency ( 5 to 10 fold) in apinene-rich environment, while optimal reaction rates were in high-water content systems 


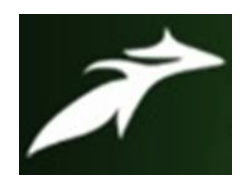

Amit Rastogi et al, International Journal of Advances in Agricultural Science \& Technology, Vol.8 Issue.12, December-2021, pg. 39-74

ISSN: 2348-1358

Impact Factor: 6.057

NAAS Rating: 3.77

$(15.5 \% \mathrm{v} / \mathrm{v})$. Laccase activity was increased 2.6 -fold with the addition of copper sulphate (10 $\mathrm{mM})$.

Among various inducers used like gallic acid $(1 \mathrm{mM})$, catechol $(1 \mathrm{mM})$, ammonium tartrate $(55 \mu \mathrm{M})$, hydroxybenzoic acid $(1 \mathrm{mM})$ and vanillin $(1 \mathrm{mM})$, it has been reported that only ammonium tartrate increased the enzymatic activity reaching to $251 \mathrm{U} \mathrm{mL}^{-1}$ of extract after 30 days in case of laccase from Lentinula edodes (Cavallazzi et al., 2005). (Valeriano et al., 2009) obtained high activity when inducers 2,5-xylidine or ethanol were used in specific concentration in case of laccase from Pycnoporus sanguineus.

\section{Effects of Surfactants}

The addition of detergents, e.g. Tween 20 or 80 , has resulted in higher yields of ligninolytic enzymes in certain fungi. There is evidence that these detergents result in higher permeability of oxygen and extracellular enzyme transport through the cell membranes of fungi (Leštan et al., 1994; Rothschild et al., 1995). Effective induction of laccase from Pleurotus floridae with anionic and cationic surfactants has been reported (Dombrovskaya and Kostyshin, 1996).

\section{Effect of Agitator}

Agitation is another factor which affects laccase production. (Hess et al., 2002) found that mycelia are damaged when fungus is grown in the stirred tank reactor and laccase production by Trametes multicolour is considerably decreased. (Mohor ${ }^{2} \mathrm{ci}^{2} \mathrm{c}$ et al., 2004) found that cultivation of white-rot fungus Bjerkandera adusta in a stirred tank reactor with very low activities was attained. (Tavares et al., 2006) observed that agitation did not play any role in the production of laccase by $T$. versicolour.

Influence of metal ions: According to (Zhang et al., 2006) laccase activity was not significantly affected by the presence of $\mathrm{Mg}^{2+}, \mathrm{Zn}^{2+}, \mathrm{Cu}^{2+}$ ions and EDTA at the concentrations of $6.25-50 \mathrm{mM}$ but was reduced by $\mathrm{Ca}^{2+}$ at $25-50 \mathrm{mM}, \mathrm{Al}^{2+}$ and $\mathrm{Fe}^{2+}$ at a concentration of $6.25-50 \mathrm{mM}$. They have also reported that Lentinula edodes laccase was inhibited in the presence of $1 \mathrm{mM} \mathrm{Ca}^{2+}(70 \%)$ and $\mathrm{Zn}^{2+}(64 \%)$ and was enhanced by $40 \%$ in the presence of $10 \mathrm{mM} \mathrm{Cu}{ }^{2+}$. (Palmieri et al., 2000) observed that the addition of $\mathrm{CuSO}_{4}$ in the production media resulted in 50-fold increase in laccase activity when compared to a basal medium without copper sulphate. Similarly, oxidation of manganese ions played an important role in the function of the lignolytic complex of wood degradation, since it efficiently oxidized certain non-phenolic compounds of lignin (Gorbacheva et al., 2009). 


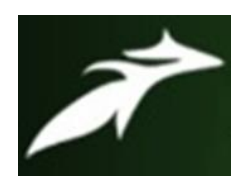

Amit Rastogi et al, International Journal of Advances in Agricultural Science \& Technology, Vol.8 Issue.12, December-2021, pg. 39-74

ISSN: 2348-1358

Impact Factor: 6.057

NAAS Rating: 3.77

(Galai et al., 2009), identified Stenotrophomonas maltophilia AAP56 a soil bacterium by biochemical and molecular methods. The effect of EDTA, sodium azide, urea, $\mathrm{Cu}^{2+}, \mathrm{Fe}^{2+}$, $\mathrm{Mn}^{2+}, \mathrm{Mg}^{2+}, \mathrm{Zn}^{2+}$ and $\mathrm{Ca}^{2+}$ was determined by incubating for 5 min at $4{ }^{\circ} \mathrm{C}$ prior to substrate addition. The laccase activity recorded $275 \mathrm{U} \mathrm{L}^{-1}$ which is increased by 2.6 -fold in the production of enzymes. They have also indicated that the enzyme was totally inhibited by the addition of EDTA, which proves it's a metal-dependent enzyme.

\section{Solid state fermentation}

Studies on fungal enzyme production in SSF have shown that SSF, in comparison with SmF, provides higher volumetric productivities, is less prone to problems with substrate inhibition and yields enzymes with a higher temperature or $\mathrm{pH}$ stability. Also, the fermentation time is shorter and the degradation of the produced enzymes by undesirable proteases is minimized. Production of laccase from different fungal sources has been also displayed through solid state fermentation. (Narayanan et al., 2015).

(Safari-Sinegani et al., 2006) reported that fungal laccase activities in extracts of solid media were higher when compared with those in extracts of liquid media. This result may be related to (1) lower deactivation of enzymes after adsorption or immobilization on agricultural residues in solid media, and/or (2) more stimulation and production of enzymes in solid media. The addition of soil to the solid media increases laccase activity significantly. It is perhaps related to soil organic matter, especially aromatics, hydrocarbons, flavonoids and trace elements.

(Narayanan et al., 2015) reported the best example of SSF for laccase production in which laccase producing bacterium, Bacillus subtilis MTCC 2414, was subjected to optimization by conventional techniques and was partially purified using ammonium salt precipitation method. In the study agro residue substrates used for higher yield of laccase were rice bran and wheat bran. Maximum production was achieved at temperature $30^{\circ} \mathrm{C}(270 \pm 2.78 \mathrm{U} / \mathrm{mL})$, $\mathrm{pH} 7.0(345 \pm 3.14 \mathrm{U} / \mathrm{mL})$, and $96 \mathrm{~h}(267 \pm 2.64 \mathrm{U} / \mathrm{mL})$ of incubation. The carbon and nitrogen sources resulted in high enzyme yield at 3\% sucrose $(275 \pm 3.11 \mathrm{U} / \mathrm{mL})$ and $3 \%$ peptone $(352.2 \pm 4.32 \mathrm{U} / \mathrm{mL})$ for rice bran and $3 \%$ sucrose $(247.4 \pm 3.51 \mathrm{U} / \mathrm{mL})$ and $3 \%$ peptone $(328 \pm 3.33 \mathrm{U} / \mathrm{mL})$ for wheat bran, respectively. The molecular weights of partially purified laccase were $52 \mathrm{kDa}$ for rice bran and $55 \mathrm{kDa}$ for wheat bran. The laccase exhibited optimal activity at $70^{\circ} \mathrm{C}(260.3 \pm 6.15 \mathrm{U} / \mathrm{mL}), \mathrm{pH} 9.0(266 \pm 4.02 \mathrm{U} / \mathrm{mL})$, and metal ion CuSO4 (141.4 \pm 6.64$)$ was found to increase the production. This is the first report that delivers the higher yield of laccase produced from B. subtilis MTCC 2414 using agro residues as a potential substrate. 


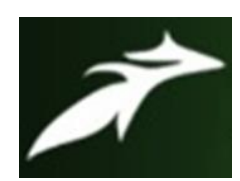

Amit Rastogi et al, International Journal of Advances in Agricultural Science \& Technology, Vol.8 Issue.12, December-2021, pg. 39-74

ISSN: 2348-1358

Impact Factor: 6.057

NAAS Rating: 3.77

\section{Use of agro-industrial waste}

The use of lignocellulosic agro-industrial residues showed their great potential as substrate for the production of high titres of laccase. Many of the researches have already reported the efficiency of many such residues, work by (Octavio et al., 2006) was one of the best among them. Sago hampas, oil palm frond parenchyma tissue (OPFPt) and rubber wood sawdust supplemented with nutrient solution and nitrogen in the form of urea were utilized as substrates with Pycnoporus sanguineus for laccase production. The study also emphasized the effect of inoculum age, density and nitrogen supplementation on laccase production, besides optimizing the efficiency of sodium-citrate buffer and tap water at different $\mathrm{pH}$ as enzyme extraction medium.

(Ellen et al., 2008) reported the potential of orange bagasse, major industrial food waste arising from processing orange for juice as solid support for laccase production from $B$. rhodiana. A good enzyme titre was seen in solid state fermentation without added nutrients, indicating nutrient sufficiency of orange bagasse at a solids concentration of $16 \%(\mathrm{w} / \mathrm{v})$ to sustain growth and high enzyme titres.

(Kapoor et al., 2009) reported the potential of wheat straw as a natural support for the production of laccase from $L$. edodes. The study has also reported the efficiency of several organic compounds such as rice bran, corn steep meal, peanut meal, soya meal and wheat bran as supplements to wheat straw for laccase production. Laccase source when cultivated on both supplemented wheat straw combinations and un-supplemented wheat straw(control), with $70 \%$ humidity, solid support with optimal concentration of supplement yielded a good growth and enzyme activity.

The study presented a new approach of utilizing the agro-industrial waste as fermentation feedstock for the production of value-added enzymes.

\section{PURIFICATION OF LACCASE}

Ammonium sulphate fractionation has been commonly used for years to partially purify laccases from the crude filtrate of their sources. However researches reported thus far have also been experimented with much efficient methodologies such as membrane filtration techniques, various chromatographic techniques and have resulted in many commercially available purified forms of enzymes.

A single-step purification procedure for Neurospora crassa laccase is reported by (Judewicz et al., 1998) using celite chromatography and obtains a specific activity of $333 \mathrm{U} \mathrm{mg}^{-1}$ with 


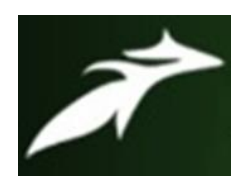

Amit Rastogi et al, International Journal of Advances in Agricultural Science \& Technology, Vol.8 Issue.12, December-2021, pg. 39-74

ISSN: 2348-1358

Impact Factor: 6.057

NAAS Rating: 3.77

54\% fold purification. (Kiiskinen et al., 2004) purified laccase from LLP13 and AH2 strains using DEAE Sepharose Fast Flow column, Phenyl Sepharose Fast Flow column. AH2 laccase was further purified with gel filtration on a Sephacryl S-100 HR column. (Han et al., 2005) purified laccase from Trametes versicolor, using ethanol precipitation, DEAE-Sepharose, Phenyl-Sepharose and Sephadex G-100 chromatography. T. versicolor 951022 excretes a single monomeric laccase showing a high specific activity of $91,443 \mathrm{U} \mathrm{mg}^{-1}$ for 2,2'-azinobis-(3-ethylbenzthiazoline-6-sulfonic acid) (ABTS) as a substrate.

(Cordi et al., 2007) purified laccase from Termetes vesicular by applying the crude extract to ion exchange DEAE Sephadex A-50 followed by gel filtration on Sephacryl S- 200-HR column in a FPLC System and find the specific activity of $101 \mathrm{U} \mathrm{mL}^{-1}$ with 34.8 fold purification. (Minussi et al., 2007) purified laccase from T. versicolor (CCT 4521) using ammonium sulphate precipitation followed by Sephacryl S-200 (Sigma) column and DEAE cellulose. They obtained a purification of 41.3 folds with 43.3 units/mg specific activity. (Khammuang et al., 2009) purified laccase from fruiting bodies of Ganoderma sp. MK05 by ammonium sulphate precipitation with 40-70\% saturation and DEAE cellulose chromatography and obtained 1.34 and 3.07 fold purification, respectively. (Viswanath et al., 2008b) purified extracellular laccase from Stereum ostrea and obtained up to 70-fold purification from the culture filtrate by a two-step protocol- ammonium sulphate $(80 \% \mathrm{w} / \mathrm{v})$ and Sephadex G-100 column chromatography. (Yang et al., 2009) purified laccase from Termetes sp. using DEAE Cellulose and Superdex-75.

\section{Molecular weight}

The molecular weight of laccase is predicted to be in the range of 50-97 $\mathrm{kDa}$ from the experimental reports. An important feature is that a covalently-linked carbohydrate moiety (10-45\% of total molecular mass), which may contribute to the high stability of the enzyme.

(Judewicz et al., 1998) have shown laccase with molecular weight $64.8 \mathrm{kDa}$. Lac IId (isozyme of laccase from Cerrena unicolor) purified by (D'Souza-Ticlo et al., 2009) showed a molecular weight of $59 \mathrm{kDa}$ and $\mathrm{pI}$ of 5.3 when analyzed by 2-D PAGE. (Han et al., 2005) purified laccase enzyme from Trametes versicolor containing molecular mass of approximately $97 \mathrm{kDa}$ as determined through SDS-PAGE, larger than those of other laccases reported thus far. The molecular mass of purified laccases from Termetes was found to be approximately $66 \mathrm{kDa}$, as reported by (Cordi et al., 2007) through calibrated gel filtration and SDS-PAGE.

Effect of inhibitors on enzyme activity: Laccase responds to inhibitors. They may inhibit enzyme activity either by binding to Type 2 or 3 copper, resulting in the interruption of 


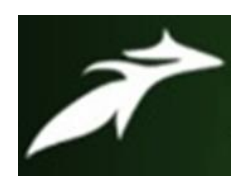

Amit Rastogi et al, International Journal of Advances in Agricultural Science \& Technology, Vol.8 Issue.12, December-2021, pg. 39-74

ISSN: 2348-1358

Impact Factor: 6.057

NAAS Rating: 3.77

internal electron transfer (metal ions such as azide halides, cyanides), amino acid modification, conformational changes of $\mathrm{Cu}$ chelation (metal ions, fatty acids, kojic acids), selective removal of $\mathrm{Cu}$ by chelating agents (EDTA, dimethylglyoxime).

Among the various inhibitors tested by (D’Souza-Ticlo et al., 2009) for Lac IId, isozyme (isozyme of laccase fom unicolor), activity was inhibited in the presence of sodium azide, SDS and mercaptoethanol. Approximately 56 and $48 \%$ of Lac IId activity was inhibited in the presence of $\mathrm{Cr}$ and $\mathrm{W}$, whereas in the presence of $\mathrm{Sn}, \mathrm{Ag}$ and $\mathrm{Hg}$ the inhibition was only 32-37\%. The other metal ions did not show significant inhibition. (Dube et al., 2008) observed that ethylene diamine tetraacetic acid (EDTA) $(5 \mathrm{mM})$ totally inhibits laccase activity. EDTA, SDS and arginine showed inhibitory effects on laccase activity (Valeriano et al., 2009).

\section{Substrate specificity and kinetic constants}

Laccases can act on a wide range of substrates. These enzymes catalyze one electron oxidation of a wide variety of organic and inorganic substrate, including polyphenols, methoxy-substituted phenols, aromatic amines and ascorbate with the concomitant four electron reduction of oxygen to water (Kunamneni et al., 2007).

.(Li et al., 2008) compared three substrates: 2,2'-azinobis-(3-ethylbenzthiazoline-6-sulfonate) (ABTS), O-dianisidine and guaiacol to assay the laccase activity from Trametes sp and obtained higher activity with ABTS as compared to others. (Tzialla et al., 2009) used various ternary systems consisting of monoterpenes (a-pinene or D-limonene), tert-butanol and water as reaction media to enhance the catalytic performance of laccases from various fungi sources (Trametes versicolor, T. hirsuta and Botrytis cinerea). The enzyme kinetic constants, $\mathrm{Km}$ and Vmax, vary from source to source, type of the substrate utilized and also other parameters used in experiment. $\mathrm{Km}$ values are in the range of 2-5000 $\mu \mathrm{M}$. The $\mathrm{Km}$ values are different for laccases from different source organisms having different substrate preference.

The Km value of the enzyme from Trametes versicolor reported by (Han et al., 2005) for substrate ABTS is $12.8 \mathrm{M}$ and its corresponding $\mathrm{V}_{\max }$ value is $8125.4 \mathrm{U} \mathrm{mg}^{-1}$. (Valeriano et $a l ., 2009)$ reported that for laccase from Stereum ostrea, $\mathrm{Km}$ and Vmax values for the substrate guaiacol were found to be $13.25 \mathrm{mM}$ and $255 \eta \mathrm{kat} \mathrm{mg}^{-1}$ of protein, respectively. In another report by (D'Souza-Ticlo et al., 2009), for the isozyme Lac IId (isozyme of laccase form C. unicolor), specificity constant (Kcat/Km) of $120 \mathrm{~min}^{-1} \mu \mathrm{M}^{-1}$ was observed with ABTS at $70^{\circ} \mathrm{C}$ and $\mathrm{pH}$ 3. (Galai et al., 2009) isolate laccase from bacteria Stenotrophomonas maltophilia AAP56. The enzyme showed $\mathrm{Km}=53 \mu \mathrm{M}$ using syringaldazine, $\mathrm{Km}=700 \mu \mathrm{M}$ using 2,2'-azino-bis(3-ethylbenzthiazoline-6- sulfonic acid) and $\mathrm{Km}=25 \mu \mathrm{M}$ using 


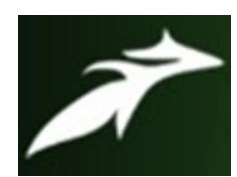

Amit Rastogi et al, International Journal of Advances in Agricultural Science \& Technology, Vol.8 Issue.12, December-2021, pg. 39-74

ISSN: 2348-1358

Impact Factor: 6.057

NAAS Rating: 3.77

pyrocatechol. The Lineweaver-Burk plot yielded a $K m$ value of $28.6 \mu \mathrm{M}$ for $\mathrm{L} 1$ and $5 \mu \mathrm{M}$ for L2 using syringaldazine as substrate, by enzyme purified from Termetes vesicular (Minussi et al., 2007).

pH and temperature: The optimum $\mathrm{pH}$ value for laccases varies depending on the substrates used, moreover many reports have reported a bell shaped profile for laccase activity. $\mathrm{pH}$ optima varies considerably due to reactions caused by substrate utilized, molecular oxygen or enzyme itself. The difference in redox potential between the phenolic substrate and the T1 copper could increase oxidation of the substrate at high $\mathrm{pH}$ values, but the hydroxide anion ($\mathrm{OH}$ binding to the T2/T3 centres). These two opposing effects can play an important role in determining the optimal $\mathrm{pH}$ of the biphasic laccase enzyme (Kunamneni et al., 2007). The optimal temperature of laccase can differ greatly from one strain to another.

(Cordi et al., 2007) reported the effect of $\mathrm{pH}$ on activity and it was found in the range 3.0-8.0, using syringaldazine as substrate. $\mathrm{L} 1$ (isozyme of laccase) showed to have $\mathrm{pH}$ in acidic range, with an optima of $\mathrm{pH} 4.0$, whereas the optimum $\mathrm{pH}$ for $\mathrm{L} 2$ was 5.0. Laccase enzyme extracted from Trametes versicolor by (Han et al., 2005) showed high enzyme activity over broad $\mathrm{pH}$ and temperature ranges with optimum activity at $\mathrm{pH} 3.0$ and a temperature of $50^{\circ} \mathrm{C}$. Laccase purified from Stereum ostrea found to be active and stable at optimal pH 6.0 and temperature $40^{\circ} \mathrm{C}$ (Valeriano et al., 2009).

Stability experiments by (Cordi et al., 2007) showed that L1 (isoenzyme of laccase) was stable at $60^{\circ} \mathrm{C}$ retaining $100 \%$ activity after $20 \mathrm{~min}$ incubation while the amount of residual activity at $70^{\circ} \mathrm{C}$ amounted to $47 \%$. On the other hand, the L2 isoenzyme was less stable retaining only $28.1 \%$ initial activity upon $20 \mathrm{~min}$ incubation at $60^{\circ} \mathrm{C}$. Two of the other isoenzymes exhibited an optimum temperature at $40^{\circ} \mathrm{C}$ and relative activities at 60 and $70^{\circ} \mathrm{C}$ were 65.0 and $37.0 \%$, respectively.

Three laccases, Lac I, Lac II and Lac III enzymes extracted from mangrove (Cerrena unicolor) by (D'Souza-Ticlo et al., 2009) of differing molecular masses were resolved by anion exchange chromatography. The optimum $\mathrm{pH}$ and temperature for Lac IId were 3 and $70^{\circ} \mathrm{C}$ respectively, the half-life at $70^{\circ} \mathrm{C}$ being $90 \mathrm{~min}$. The enzyme was most stable at $\mathrm{pH} 9$ and retained $>60 \%$ of its activity up to $180 \mathrm{~min}$ at 50 and $60^{\circ} \mathrm{C}$.

\section{Isozymes of laccase}

Many laccase producing fungi secrete isoforms of the same enzyme. These isozymes have been found to originate from the same or different genes encoding for the laccase enzyme. 


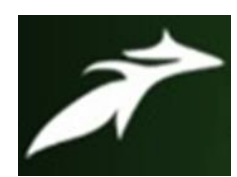

Amit Rastogi et al, International Journal of Advances in Agricultural Science \& Technology, Vol.8 Issue.12, December-2021, pg. 39-74

ISSN: 2348-1358

Impact Factor: 6.057

NAAS Rating: 3.77

The number and of isoforms vary with species and also within species. The biochemical characteristics of isoenzymes vary depending upon the source and culture conditions.

(Cordi et al., 2007) reported two isoenzyme forms of laccase from Trametes sp. Two laccase isoenzymes (POXA1 and POXA2) produced by Pleurotus ostreatus with molecular weight of 61 and $67 \mathrm{kDa}$, pI of 6.7 and 4, respectively (Palmieri et al., 1997). (Mansur et al., 2003) reported four laccase isozymes (LCC1, LCC2, LCC3 and LCC4) synthesized by Pleurotus ostreatus strain V-184 were purified and characterized. LCC1 and LCC2 have molecular masses of about 60 and $65 \mathrm{kDa}$ and showed the same pI value (3.0). Laccases isozymes LCC3 and LCC4 were characterized by SDS-PAGE, estimating their molecular masses around 80 and $82 \mathrm{kDa}, \mathrm{pI} 4.7$ and 4.5, respectively. When staining with ABTS and guaiacol in native polyacrylamide gels, different specificities were observed for LCC1/LCC2 and LCC3/LCC4 isozymes whereas (D’Souza-Ticlo et al., 2009) reported three laccase isoenzymes Lac I, Lac II and Lac III from C. unicolor had significantly varying biochemical characteristics.

A single organism may also possess several laccase isozymes (or isoforms) that may differ in their amino acid sequence and display different kinetic properties towards standard laccase substrates. Four different laccase isozymes have been detected in the basidiomycete Rhizoctonia solani (Wahleithner et al., 1996) and the ascomycete Fusarium proliferatum (Kwon and Anderson, 2001). Fungi may produce several isozymes of laccase that differ from one another with respect to both the degree of glycosylation and type of carbohydrate residues. An example of this is Trametes versicolor that was found to produce five isozymes differing only in carbohydrate content (Bertrand et al., 2002). The carbohydrate content of laccases may constitute 10 to $45 \%$ of the molecular mass of the protein (Yaropolov et al., 1994), and in fungal laccases this usually constitutes between 15 and $20 \%$ of the molecular mass (Thurston, 1994).

\section{APPLICATIONS OF LACCASE}

Laccases have many biotechnological applications due to their oxidation ability towards a broad range of phenolic and non-phenolic compounds (Mohammadian et al., 2010). Biotechnological application of laccases towards the oxidation of phenolic and non-phenolic compounds includes bioremediation of lignocellulosic waste containing phenolic and nonphenolic as well as extremely residual compounds from pulp and paper mill, food industries, sugarcane molasses-based distilleries and agricultural waste (Kumar et al., 2020), bioremediation of phenolic and non phenolic toxic and hazardous compounds from soil such as pentachlorophenols (PCP), polychlorinated biphenyls (PCB), polycyclic aromatic hydrocarbons (PAH), 1,1,1-trichloro-2,2-bis(4-chlorophenyl) ethane (DDT), benzene, 


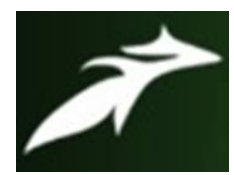

Amit Rastogi et al, International Journal of Advances in Agricultural Science \& Technology, Vol.8 Issue.12, December-2021, pg. 39-74

ISSN: 2348-1358

Impact Factor: 6.057

NAAS Rating: 3.77

toluene, ethylbenzene, and xylene (BTEX) as well as trinitrotoluene (Upadhyay et al., 2016), bioremediation of phenolic and non-phenolic textile dyes (Upadhyay et al., 2016, Shraddha et $a l ., 2011)$, laccase based biosensors for detection of hazardous phenolic compound in waste water and detection of phenols, such as catechols in tea as well polyphenolic compounds in wine (Upadhyay et al., 2016).

Other applications of laccase include the cleaning of the industrial effluents, mostly from industries like paper industry, pulp, textile \& petrochemical industries. Laccase can be used in medical diagnostics and for cleaning herbicides, pesticides and some explosives in soil. Laccase has been reported to have many applications in agricultural, medicinal and industrial areas (Arora and Sharma, 2010). Laccases are also used to clean the water in many purification systems. It also has applications in the medical field to prepare assured drugs like anticancer drugs and it is added in cosmetics to minimize their toxic effects. Laccase has the enormous ability to remove xenobiotic substances and produce polymeric products and that is why they are being used for many bioremediation purposes (Couto and Herrera, 2006). Now researchers are working on enzymatic synthesis of organic compounds, laccase-based biooxidation, and biotransformation and biosensor development. The yield of laccase can be accessed by optimizing different cultural conditions (Arora and Sharma, 2010). Different applications of laccases are given in figure 4.

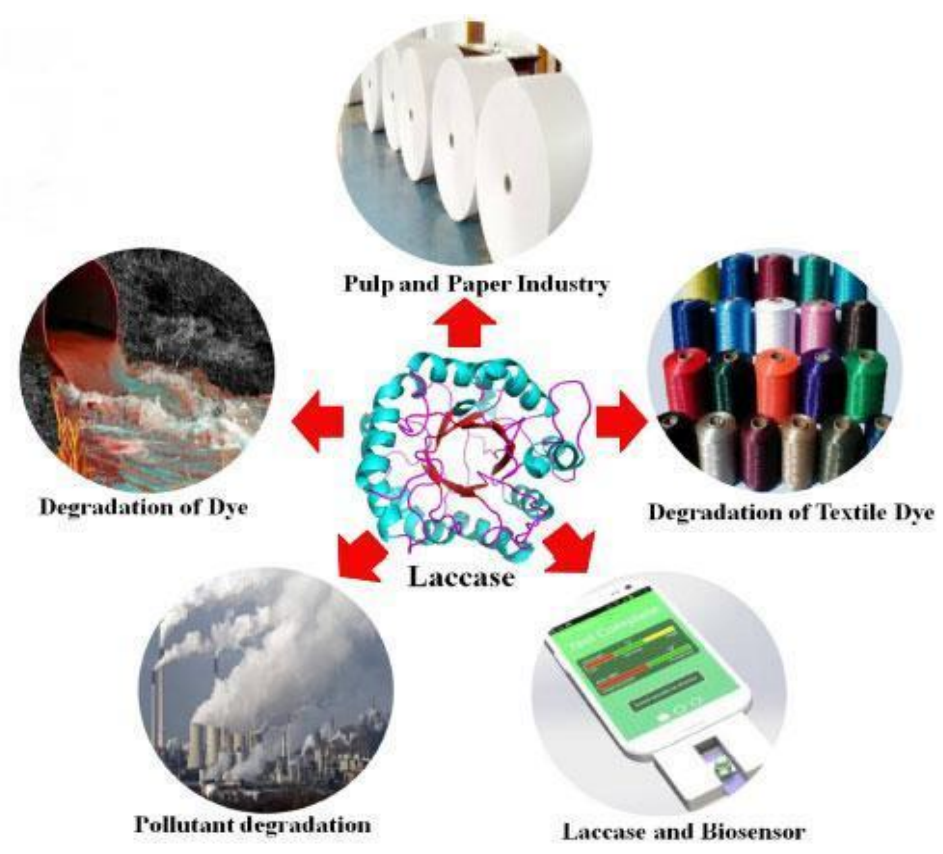

Figure 4: Different applications of laccases 


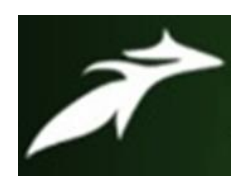

Amit Rastogi et al, International Journal of Advances in Agricultural Science \& Technology, Vol.8 Issue.12, December-2021, pg. 39-74

ISSN: 2348-1358

Impact Factor: 6.057

NAAS Rating: 3.77

\section{Applications of laccase in textile industry}

Synthetic dyes are widely used in such industries as textile, leather, cosmetics, food and paper printing (Forgacsa et al., 2004). Reactive dyes are coloured molecules used to dye cellulose fibres (Tavares et al., 2009). These dyes result in the production of large amounts of high-colored wastewater. A special problem is found in the application of synthetic dyes that are resistant to biodegradation (Wesenberg et al., 2003, Moilanen et al., 2010). Normally, from 10 to $50 \%$ of the initial dye load will be present in the dyebath effluent, giving rise to a highly coloured effluent (Vandevivere et al., 1998; Moilanen et al., 2010). Therefore, the treatment of industrial effluents containing aromatic compounds is necessary ahead to final discharge to the environment (Khlifia et al., 2010). Nowadays, environmental regulations in most countries require that wastewater must be decolorized before its discharge (Moilanen et al., 2010) to reduce environmental problems related to the effluent (Tavares et al., 2009). A wide range of physicochemical methods has been developed for the degradation of dyecontaining wastewaters (Vandevivere et al., 1998, Tavares et al., 2009). Wastewaters from textile dying process are usually treated by physical or chemical processes, which contain physical-chemical processes electrokinetic coagulation, electrochemical destruction, irradiation, precipitation, ozonation, or the Katox method that involves the use of active carbon and the mixture of certain gases (air) (Banat et al., 1996, Tavares et al., 2009, Khlifia et al., 2010). However, due to the chemical nature, molecular size and structure of the reactive dyes these classical processes can cause a problem in the environment and better treatments can be obtain dusing bioprocesses (Tavares et al., 2009). The waste water from textile industries is high in BOD and COD, can harm to aquatic and human life, can affect photosynthesis, inhibit plant growth, enter the food chain, provide recalcitrance and bioaccumulation, and may promote toxicity, mutagenicity and carcinogenicity (Cíntia et al., 2019). Recently, enzymatic treatments have attracted much interest in the decolourization/degradation of textile dyes in wastewater as an alternative way to conventional chemical and physical treatments, which present serious limitations (Cristovao et al., 2008, Tavares et al., 2009). Five indigenous fungi $P$. ostreatus IBL-02, $P$. chrysosporium IBL-03, Coriolus versicolor IBL- 04, G. lucidum IBL-05 and S. commune IBL-06 were screened for decolorization of four vat dyes, Cibanon red 2B-MD, Cibanon golden-yellow PKMD, Cibanon blue GFJ-MD and Indanthrene directblack RBS. The screening experiment was run for 10 days with $0.01 \%$ dye solutions prepared in alkaline Kirk's basal nutrient medium in triplicate $(250 \mathrm{ml}$ flasks). Every $48 \mathrm{~h}$ samples were read on their respective wavelengths to determine the percent decolorization. It was checked that $C$. versicolor IBL-04 could effectively decolorized all the four vat dyes at varying incubation times but best results were shown on Cibanon blue GFJ-MD (90.7\%) after 7 days, followed 


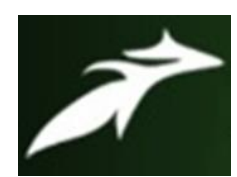

Amit Rastogi et al, International Journal of Advances in Agricultural Science \& Technology, Vol.8 Issue.12, December-2021, pg. 39-74

ISSN: 2348-1358

Impact Factor: 6.057

NAAS Rating: 3.77

by golden yellow (88\%), Indanthrene direct black (79.7\%) and Cibanon red (74\%). $P$. chrysosporium also showed good decolorization potential on Cibanon blue (87\%), followed by Cibanon golden-yellow (74.8\%), Red (71\%), and Indanthrene direct black (54.6\%) (Asghar et al., 2008). Decolourization and detoxification of a textile industry effluent by laccase from Trametes trogii in the presence and the absence of laccase mediators had been reported. It was found that laccase alone was not able to decolourize the effluent efficiently even at the highest enzyme concentration tested: less than $10 \%$ decolourization was obtained with $9 \mathrm{U} / \mathrm{mL}$ reaction mixtures. To enhance effluent decolourization, several potential laccase mediators were tested at concentrations ranging from 0 to $1 \mathrm{mM}$. Most potential mediators enhanced decolourization of the effluent, with 1- hydroxybenzotriazol (HBT) being the most effective (Khlifia et al., 2010). (Moilanen et al., 2010) used the crude laccases from the white-rot fungi Cerrena unicolor and Trametes hirsuta for their ability to decolorize simulated textile dye baths. The dyes used were Remazol Brilliant Blue R (RBBR) (100 $\mathrm{mg} / \mathrm{L})$, Congo red (12.5 mg/L), Lanaset Grey (75 mg/L) and Poly R-478 (50 mg/L). They assessed the effect of redox mediators on dye decolorization by laccases. The result was that C. unicolor laccase was able to decolorize all the dyes tested. It was especially effective towards Congo red and RBBR with 91 and $80 \%$ of color removal in $19.5 \mathrm{~h}$ despite the fact that simulated textile dye baths were used.

\section{APPLICATION OF LACCASE IN FOOD INDUSTRIES Wine stabilization}

Laccase can be used to improve the quality of drinks and for the stabilization of certain perishable products containing plant oils (Morozova et al., 2007). In the food industry, wine stabilization is one of the main applications of laccase (Duran and Esposito, 2000; Rosana et al., 2002). Laccases are utilized in wine stabilization by removing polyphenols from wine (Minussi et al., 2007). Polyphenols have undesirable effects on wine production and on its organoleptic characteristics, so their removal from the wine is very necessary (Rosana et al., 2002). Many innovative treatments, such as enzyme inhibitors, complexing agents, and sulfate compounds, have been suggested for the removal of phenolics responsible for discoloration, haze, and flavour changes but the possibility of using enzymatic laccase treatments as a specific and mild technology for stabilizing beverages against discoloration and clouding represents an attractive alternative (Cantarelli et al., 1989; Arora and Sharma, 2010). Since such an enzyme is not yet allowed as a food additive, the use of immobilized laccase might be a suitable method to overcome such legal barriers as in this form it may be classified as technological aid. So laccase could find application in preparation of must, wine and in fruit juice stabilization (Minussi et al., 2002; Arora and Sharma, 2010). 


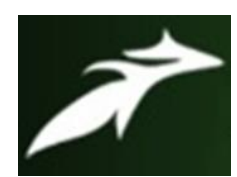

Amit Rastogi et al, International Journal of Advances in Agricultural Science \& Technology, Vol.8 Issue.12, December-2021, pg. 39-74

ISSN: 2348-1358

Impact Factor: 6.057

NAAS Rating: 3.77

\section{Baking industry}

In the bread-making process laccases affix bread and/or dough-enhancement additives to the bread dough, these results in improved freshness of the bread texture, flavour and the improved machinability (Minussi et al., 2002). Laccase is also one of the enzymes used in the baking industry. Laccases are currently utilized in baking due to their ability to cross-link biopolymers. Laccases are used in baking to increase strength, stability, and reduce stickiness and to improve machinability of the dough. Moreover, laccases provides an increased volume and an improved crumb structure and softness of the baked product (Osma et al., 2010). Laccase enzyme is added in the baking process which results in the oxidizing effect, and also improves the strength of structures in dough and/or baked products. Laccase imparts many characteristics to the baked products including an improved crumb structure, increased softness and volume. A flour of poor quality can be also used in this process using laccase enzyme (Minussi et al., 2002).

\section{Applications in pharmaceutical industry}

Laccases can be used for the synthesis of several products of the pharmaceutical industry (Arora and Sharma, 2010). The first chemical of pharmaceutical importance that has been prepared using laccase enzyme is actinocin which was prepared from 4-methyl-3hydroxyanthranilic acid. This compound has anticancer capacity and works by blocking the transcription of DNA from the tumor cell (Burton, 2003). Another example of the anticancer drugs is Vinblastine, which is useful for the treatment of leukemia. The plant Catharanthus roseus naturally produces vinblastine. This plant produces a small amount of this compound. Katarantine and vindoline are the precursors of this pharmaceutically important compound. These precursors are produced in higher quantities and are easy to purify. Laccase is used to convert these precursors into vinblastine. A $40 \%$ conversion of these precursors into the final product has been obtained using laccase (Yaropolov et al., 1994). The role of laccase in such conversion reactions has proved the preparation of several important compounds with useful properties, like antibiotics, possible (Pilz et al., 2003). Catechins have the antioxidant ability and Laccases can oxidize catechins. These catechins consist of small units of tannins and these are important antioxidants found in tea, herbs and vegetables. Catechins have the tendency to hunt free radicals and their property makes them useful in preventing several diseases including cancer, inflammatory and cardiovascular diseases. The catechins have less antioxidant ability; this property can be increased by using laccase and has resulted in the conversion of catechins in several products with enhanced antioxidant capability (Kurisawa et al., 2003). Laccase can be used in the synthesis of hormone derivatives. (Nicotra et al., 2004, Intra et al., 2005) have reported that laccase has the ability to seperate innovative dimeric derivatives of the $\beta$-estradiol and of the phytoalexin resveratrol. Isoeugenol oxidation 


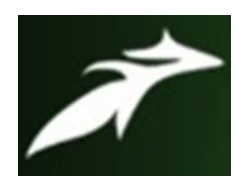

Amit Rastogi et al, International Journal of Advances in Agricultural Science \& Technology, Vol.8 Issue.12, December-2021, pg. 39-74

ISSN: 2348-1358

Impact Factor: 6.057

NAAS Rating: 3.77

coniferyl alcohol and totarol gave new dimeric derivatives (Ncanana et al., 2007) and a mixture of dimeric and tetrameric derivatives (Shiba et al., 2000) respectively, whereas the oxidation of substituted imidazole has resulted in the production of even more complex substances. These newly formed imidazoles or oligomerization products (2-4) can be used for pharmacological purposes (Kurisawa et al., 2003). Aromatic and aliphatic amines can be converted into 3-(3, 4-dihydroxyphenyl)-propionic acid using laccase based oxidation. The derivatives have_antiviral natural activity and can be used for pharmaceutical purposes (Ncanana et al., 2007).

\section{Paper and pulp industry}

In the industrial preparation of paper, the separation and degradation of lignin in wood pulp are conventionally obtained using chlorine- or oxygen-based chemical oxidants. Although the LMS has been studied extensively, there are still unresolved problems concerning mediator recycling, cost and toxicity. However, some environmental benefits are envisaged and the fact that LMS could be easily implemented in the existing bleaching sequences is seen as a major advantage that could possibly lead to a partial replacement of $\mathrm{CO}_{2}$ in pulp mills (Kunamneni et al., 2007).

Pulp bleaching is currently achieved by treating pulps with chlorine-based chemicals. This results in the formation of chlorinated aliphatic and aromatic compounds that could be keenly toxic, mutagenic and carcinogenic (Monteiro and Carvalho, 1998, Bermek et al., 2004). In recent years there have been intensive studies performed to develop enzymatic, environmentally benign, bleaching technologies (Crestini and Argyropoulos, 1998, Bermek et $a l .$, 2004). The use of laccase-mediated systems has shown potential for the bio-bleaching of pulp, but the feasibility of its use is hindered by the lack of an inexpensive mediator (Bermek et al., 2004).

The bioremediatory role of laccases in the pulp and paper industry is arrest by the alkalinity of the effluent. Thus several researchers have spent considerable effort in identifying laccases that could be suitable for this type of remediation. The laccase from Coriolopsis gallica has been implicated in the decolourisation of alkaline effluents such as the effluent from the pulp and paper industry (Calvo et al., 1998). Laccases have also been shown to be applicable to the bioremediation of pulp and paper industry waste by effecting direct dechlorination (Taspinar and Kolankaya, 1998) and the removal of chorophenols and chlorolignins from bleach effluents (Milstein et al., 1989).

\section{Immunoassay}

Laccases showed application as the conjugate enzymes in enzyme linked immunoassays (EIA) due to both their high catalytic constants and the use of air oxygen as the co-substrate 


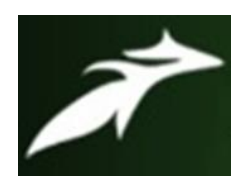

Amit Rastogi et al, International Journal of Advances in Agricultural Science \& Technology, Vol.8 Issue.12, December-2021, pg. 39-74

ISSN: 2348-1358

Impact Factor: 6.057

NAAS Rating: 3.77

(Yaropolov et al., 1994). Several factors making laccases suitable alternatives to peroxidases, such as horse-radish peroxidases, have been identified. A major advantage of laccases for EIA is the use of dioxygen rather than peroxide as the co-substrate, and thus there is less inactivation of the conjugate enzyme laccase by oxidation (Buchanan and Nicell, 1997; Wu et al., 2010, Aktaş et al., 2003), and no formation of unproductive enzyme-substrate complexes (Yaropolov et al., 1994). Moreover, peroxidases include a lower sensitivity to the content of variable valence metallic ions in the medium (Yaropolov et al., 1994). Since the substrates are the same for both enzymes, it is possible to substitute laccase for peroxidase and still use the same equipment and reagents in the immunoassay (Yaropolov et al., 1994). The advantages of oxygen as a co-substrate include the abundance of oxygen in the reaction, whereas hydrogen peroxide can only be added in low concentrations, since excess may lead to oxidation of the enzyme. Another disadvantage of low concentrations of the co-substrate is that it leads to the formation of unproductive enzyme-substrate complexes (Yaropolov et al., 1994). A constant supply of hydrogen peroxide may be achieved by the addition of glucose and glucose oxidase, but the addition of these increases the cost of the process.

\section{Biosensors and Biofuel Cells}

Laccases are being used in biosensor technology due to its broad substrate range allowing for the detection of a broad range of phenolics (Kuznetsov et al., 2001), this does however disallow the detection of specific constituents. Biosensors that utilize laccase include an electrode that may be used for the detection of phenols, such as catechols in tea (Ghindilis et al., 1992), phenolic compounds in wine, and lignins and phenols in wastewaters (Yaropolov et al., 1994). Novel biosensors have been developed using beneficial properties of laccase includes the potentiometric immunosensor for the detection of antigens (Yaropolov et al., 1994). Laccase showed a significant potential for its use in biofuel cells (Tayhas et al., 1999). The major reason for this interest is the use of oxygen as a substrate, which is converted into water. The main advantage of this is the potential use in nanotechnology for medical applications in living animals, since oxygen may be scavenged from the bloodstream, while the byproduct (water) is benign. The limiting factor of using laccase in this technology is its inability to reduce oxygen at the physiological $\mathrm{pH}$ of blood, a technical hurdle that must be overcome.

\section{Organic Synthesis}

Recently, increasing interest has been focused on the application of laccase as a new biocatalyst in organic synthesis (Milstein et al., 1989, Mayer et al., 2002,). Laccases are utilized in synthetic chemistry to be applicable for production of complex polymers and medical agents. Additionally, the application of laccase in organic synthesis has increased 


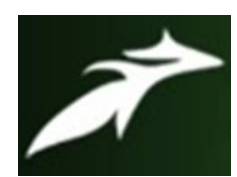

Amit Rastogi et al, International Journal of Advances in Agricultural Science \& Technology, Vol.8 Issue.12, December-2021, pg. 39-74

ISSN: 2348-1358

Impact Factor: 6.057

NAAS Rating: 3.77

due to its broad substrate range, and the conversion of substrates to unstable free (cation) radicals that may undergo further non-enzymatic reactions such as polymerization or hydration(Kunamneni et al., 2008). Laccase provided an environmentally benign process of polymer production in air without the use of $\mathrm{H}_{2} \mathrm{O}_{2}$ (Kobayashi et al., 2003, Mita et al., 2003). Laccase-catalyzed cross-linking reaction of new urushiol analogues for the preparation of "artificial urushi" polymeric films (Japanese traditional coating) was demonstrated (Ikeda et al ., 2001). It is also reported that laccase induced radical polymerization of acrylamide with or without mediator (Ikeda et al., 1998, Budolfsen et al ., 2004). Laccases are also known to polymerize various amino and phenolic compounds ( Aktas et al., 2003, Karamyshev et al., 2003). Recently, to improve the production of fuel ethanol from renewable raw materials, laccase from $T$. versicolor was expressed in $S$. cerevisiae to increase its resistance to (phenolic) fermentation inhibitors in lignocellulose hydrolyzates (Larsson et al ., 2001). The preparation of cross linked enzyme aggregrates with aldehydes and amines had improved stability and was used in starch oxidation (Schoevaart et al., 2006). Selective oxidation of the primary hydroxyl groups of sugars using the LMS is described in patent literature dealing with the partial oxidation of cellulose and other polysaccharides (Palonen and Viikari et al ., 2004, Cañas et al ., 2010). Also, LMS was used for the determination of monoclonal antibodies of azelaic acid from oleic acid (Kimura, 2006). The enzymatic preparation of polymeric polyphenols by the action of laccases has been investigated extensively in the past decades as a viable and non-toxic alternative to the usual formaldehyde-based chemical production of these compounds (Takahara, 2004, An et al., 2005). The enzymatic preparation of polymeric polyphenols by the action of laccases is viable and non-toxic alternative to the usual formaldehyde-based chemical production of these compounds (Kunamneni et al., 2008). Laccases are being used to synthesize various functional organic compounds including polymers with specific mechanical/electrical/optical properties, textile dyes, cosmetic pigments, flavor agents, and pesticides (Schouten et al., 2002, Kudanga et al., 2017).

\section{Degradation of Xenobiotics}

Laccases showed broad substrate specificity and is thus able to oxidize a broad range of xenobiotic compounds including chlorinated phenolics (Torres et al., 2003), pesticides (Pozdnyakova et al., 2004), and polycyclic aromatic hydrocarbons (Pointing et al., 2001). Moreover, polycyclic aromatic hydrocarbons, which arise from natural oil deposits and utilization of fossil fuels, were also found to be degraded by laccases (Bressler et al., 2000). Laccase purified from a strain of Coriolopsis gallica oxidized carbozole, N-ethylcarbozole, fluorine, and dibenzothiophene in presence of 1-hydroxybenzotriazole and 2.2'-azinobis (3ethylbenzthiazoline)-6-sulfonic acid as free radical mediators (Dec et al., 2000). Laboratory experiments have shown that phenols and aromatic amines may be removed from water by 


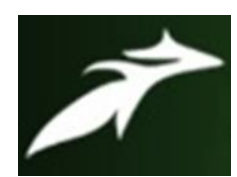

Amit Rastogi et al, International Journal of Advances in Agricultural Science \& Technology, Vol.8 Issue.12, December-2021, pg. 39-74

ISSN: 2348-1358

Impact Factor: 6.057

NAAS Rating: 3.77

the application of laccase (Niku-Paavola et al., 2000). The underlying mechanism of the removal involves enzymatic oxidation of the pollutants to free radicals or quinones that undergo polymerization and partial precipitation (Niku-Paavola et al., 2000). Laccase from white-rot fungus, Trametes hirsuta, has been used to oxidize alkenes (Bollag et al., 1992). The oxidation is the effect of a two-step process in which the enzyme first catalysed the oxidation of primary substrate, a mediator added to the reaction, and then the oxidized mediator oxidizes the secondary substrate, the alkene, to the corresponding ketone or aldehyde. In addition to substrate oxidation, laccase can also immobilize soil pollutants by coupling to soil humic substances - a process analogous to humic acid synthesis in soils (Ahn et al., 2002). The xenobiotics which can be immobilized in this way include phenolic compounds including chlorinated phenols and anilines such as 3, 4-dichloroaniline, 2, 4, 6trinitrotoluene, or chlorinated phenols (Gelo-Pujic et al., 1999). The immobilization lowers the biological availability of the xenobiotics and thus their toxicity. A laccase produced in the yeast, Pichia pastoris, was engineered by site-directed mutagenesis to improve the rate of electron transfer between the copper-containing active site of laccase and an electrode (Riu et $a l .$, 1998). Thus laccase may be usefully engineered to improve the efficiency of particular bioremediation processes.

\section{Decolourisation of Dyes}

The textile industry stands for two-thirds of the total dyestuff market and consumes large volumes of water and chemicals for wet processing of textiles (Banat et al., 1996). The chemical reagents used are very diverse in chemical composition, ranging from inorganic compounds to polymers and organic products (Zollinger, 2002). There are about 1,00,000 commercially available dyes with over $7 \times 105$ tonnes of dyestuff produced annually (Poots et al., 1976). Due to their chemical structure dyes are resistant to fading on exposure to light, water, and different chemicals and most of them are difficult to decolourise due to their synthetic origin.

Government legislation is becoming more and more stringent, especially in the more developed countries, regarding the removal of dyes from industrial effluents (McKay, 1979). Government become more stringent in developed countries because the waste water from textile industries is high in BOD and COD, can harm to aquatic and human life, can affect photosynthesis, inhibit plant growth, enter the food chain, provide recalcitrance and bioaccumulation, and may promote toxicity, mutagenicity and carcinogenicity (Cíntia et al., 2019). Concern arises as several dyes are made from known carcinogens such as benzidine and other aromatic compounds (Hou et al., 2004). Most currently existing processes to treat dye wastewater are ineffective and not economical. Therefore, the 


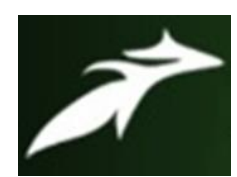

Amit Rastogi et al, International Journal of Advances in Agricultural Science \& Technology, Vol.8 Issue.12, December-2021, pg. 39-74

ISSN: 2348-1358

Impact Factor: 6.057

NAAS Rating: 3.77

development of processes based on laccases seems an attractive solution due to their potential in degrading dyes of diverse chemical structure (Couto et al., 2006) including synthetic dyes currently employed in the industry (Setti et al., 1999). The use of laccase in the textile industry is growing very fast since, besides decolorizing textile effluents as commented above, laccase is used to bleach textiles and even to synthesize dyes(Raghukumar, 2000). Flavodon flavus decolourized several synthetic dyes such as Azure B and Brilliant Blue R in low nitrogen medium (Soares et al., 2001). Alternatively, laccase, along with stabilizers is suitable for treatment of wastewater (Abadulla et al., 2000, Rodríguez et al., 1999). Partial decolorization of two azo dyes and complete decolorization of two triphenylmethane dyes (bromophenol blue and malachite green) was achieved by cultures of Pycnoporus sanguineus producing laccase as the sole phenoloxidase (Yaver et al., 1996, Saratale et al., 2010). (Enayatizamir et al., 2011) demonstrated employing HPLC analysis, the degradation of the dye "Navy blue HER" by fungus Trichosporon beigelii NCIM-3326 after one day under static conditions for the identification of metabolic products from dye degradation. (Miranda et al., 2013) reported degradation of $92 \%$ in the Azo Black Reactive 5 dye by $P$. chrysosporium after 3 days of treatment. P. chrysosporium URM 6181 and Curvularia lunata URM 6179 strains decolourize effluent containing textile indigo dye by approximately 95\% for 10 days of treatment (Annibale et al., 2000). Laccase purified from the fungus Trametes hirsuta was able to degrade triarylmethane, indigoid, azo, and athraquinonic dyes used in dyeing textiles as well as 23 industrial dyes (Ying et al., 2002).

\section{Effluent Treatment}

Laccases from fungi offer several advantages of great interest to biotechnological applications of industrial effluent treatment. As laccases showed broad substrate specificity, so they can bleach Kraft pulp or detoxify agricultural byproducts including olive mill wastes or coffee pulp (Heemken et al., 2001). Laccase of an isolate of the fungus, Flavodon flavus, was reported to decolourize the effluent from a Kraft paper mill bleach plant (Soares et al., 2001). Laccase purified from white-rot basidiomycete, Trametes villosa, degrades bisphenol A, an endocrine-disrupting chemical (Raghukumar et al., 2000). Nonylphenols have increasingly gained attention because of their potential to mimic the action of natural hormones in vertebrates (Lyons et al., 2003). They result from incomplete biodegradation of nonylphenol polyethoxylates (NPEOs), which have been widely used as nonionic surfactants in industrial processes. Both nonylphenols and NPEOs are discharged into the environment, mainly due to incomplete removal of wastewater treatment facilities (Lyons et al., 2003). Nonylphenols are more resistant to biodegradation than their parent compound and hence are found worldwide in wastewater treatment plant effluents and rivers (Bermek et al., 2004). Due to their hydrophobicity, they tend to be absorbed onto surface water particles and 


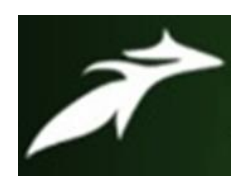

Amit Rastogi et al, International Journal of Advances in Agricultural Science \& Technology, Vol.8 Issue.12, December-2021, pg. 39-74

ISSN: 2348-1358

Impact Factor: 6.057

NAAS Rating: 3.77

sediments and accumulate in aquatic organisms. Consequently, nonylphenols represent a serious environmental and human health risk. Laccases from aquatic hyphomycete, Clavariopsis aquatica, have reported to degrade xenoestrogen nonylphenol (Calvo et al., 1998). In addition to the potential role of such degradation processes for natural attenuation processes in freshwater environments, this enzyme laccase also offers new perspectives for biotechnological applications such as wastewater treatment

\section{Potential new laccase-based biocatalysts}

Enzymatic catalysis in organic solvents is a new field of biotechnological applications of enzymes. The ability to use enzymes in non-aqueous solvents greatly expands the potential scope and economic impact of biocatalysis. When biological catalysts are placed in this unnatural environment they exhibit a number of remarkable novel properties such as altered stereo-selectivity, enhanced stability and increased rigidity (Bassanini et al., 2021). There is also facilitated recovery of products and biocatalyst (Mate et al., 2017). As well in the presence of organic solvents there is less risk of microbial contamination (Brink et al., 1988). In the specific case of laccases or LMS, many of their non-natural substrate are hardly soluble in water (their $\mathrm{Km}$ values are far away from their solubility in aqueous media), and therefore the use of cosolvents is an indispensable requirement. However, the laccase may be denatured or it may be inhibited under these conditions (Luterek et al., 1998, RodakiewiczNowak et al., 2000). In this regard laccases can be applied in nonaqueous solution or multiphasic systems. For water-immiscible organic solvents, laccase may be entrapped in reverse micelles or immobilized onto a carrier (Xu, 1999, Duran et al., 2002, Salas et al., 2019). Preferably, the reverse micelles are used in the presence of laccase mediators to enhance and mediate the laccase activity in organic solvents. Solid phase enzyme kinetics screening in microcolonies provide higher throughput, better solvent resistance and ease of handling (Salas et al., 2019). In a recent investigation directed molecular evolution of laccases was carried out for organic co-solvents resistance (Nair et al., 2013). The $M$. thermophila laccase expressed in S. cerevisiae was engineered by in vitro evolution in the presence of increasing concentrations of acetonitrile and ethanol. The turnover rates of mutant enzymes at high concentrations of organic solvents were several fold improved (our laboratory has already performed new cycles of in vitro evolution, achieving high activities at solvent concentrations as high as $50 \%$ (v/v) (unpublished material).

\section{Other laccase applications}

\section{Soil bioremediation}

Polycyclic aromatic hydrocarbons (PAHs) together with other xenobiotics are a major source of contamination in soil and their degradation is of great importance for the environment. The 


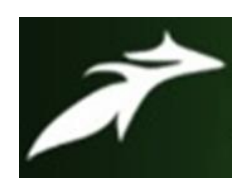

Amit Rastogi et al, International Journal of Advances in Agricultural Science \& Technology, Vol.8 Issue.12, December-2021, pg. 39-74

ISSN: 2348-1358

Impact Factor: 6.057

NAAS Rating: 3.77

catalytic properties of laccases can be utilized to degrade such compounds. Thus, laccases were able to mediate the coupling of reduced 2,4,6-trinitrotoluene (TNT) metabolites to an organic soil matrix, which resulted in detoxification of the munition residue (Durán and Esposito, 2000). Moreover, PAHs, which arise from natural oil deposits and utilisation of fossil fuels, were also found to be degraded by laccases (Pointing, 2001). Recently, (Nyanhongo et al., 2002) showed that a laccase from Trametes modesta was involved in immobilization of TNT degradation products.

\section{Synthetic chemistry}

In the future laccases may also be of great interest in synthetic chemistry, where they have been proposed to be applicable for oxidative deprotection (Semenov et al., 1993) and production of complex polymers and medical agents (Xu, 1999, Mai et al., 2000; Uyama and Kobayashi, 2002; Kurisawa et al., 2003; Nicotra et al., 2004). Recently, (Mustafa et al., 2005) synthesized phenolic colorants by using an industrial laccase named Suberase (Novo Nordisk A/S, Bags-vaerdt, Denmark).

\section{Cosmetics}

The cosmetic world has not been indifferent to the application of laccase: for example, laccase-based hair dyes are less bother and easier to handle than current hair dyes, since laccases replace $\mathrm{H}_{2} \mathrm{O}_{2}$ as an oxidizing agent in the dye formulation (Roure et al., 1992, Aaslyng et al., 1999, Lang and Cotteret, 1999). More recently, cosmetic and dermatological preparations containing proteins for skin lightening have also been developed (Golz-Berner $e t$ al., 2004).

\section{CONCLUSION}

Laccases are a widely studied group of enzymes. However, there is a great need to discover laccase from bacterial sources because bacterial laccases are cost effective, most of them are thermo stable and are able to work at a broad range of $\mathrm{pH}$ during their industrial applications. There is also a great need to introduce new production media for laccase production during submerged fermentation for better yield of enzymes. During solid state fermentation technique for laccase production, there is a great need to utilize cost effective substrate such as black grapes, banana peel etc. for laccase production. There is also a great need to develop new immobilization procedures for laccase to enhance its activity which is essential for different industrial applications. For purification of laccase new purification techniques such as HPLC should also be utilized instead of column chromatography or ion-exchange chromatography. New applications of laccase should also be introduced such as fabrication of biosensors etc. 


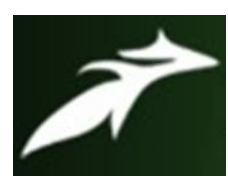

Amit Rastogi et al, International Journal of Advances in Agricultural Science \& Technology, Vol.8 Issue.12, December-2021, pg. 39-74

ISSN: 2348-1358

Impact Factor: 6.057

NAAS Rating: 3.77

\section{REFERENCES}

[1] Call, H. P., and I. Mücke, (1997), History, overview and applications of mediated ligninolytic systems, especially laccasemediator-systems (Lignozym®-process) J. Biotechnol., 53: 163-202.

[2] Gianfreda, L., F. Xu and J. M. Bollag, (1999), Laccases: A useful group of oxidore ductive enzymes. Bioremed. J., 3: 126

[3] A.I. Yaropolov, O.V. Skorobogat'ko, S.S. Vartanov, and S.D. Varfolomeyev, (1994), Laccase: Properties, catalytic machanism, and applicability, Appl. Biochem. Biotechnol., 49: 257-280.

[4] V.V. Kumar, S.D. Kirupha, P. Periyaraman and S. Sivanesan, (2011), Screening and induction of lacasse activity in fungal specied and its application in dye decolorization, African journal of Microbiology Research, 5(11): 1261-1267.

[5] Ragusa, S., M. T. Cambria, F. Pierfederici, A. Scirè, E. Bertoli, F. Tanfani, and A. Cambria., (2002), Structure-activity relationship on fungal laccase from Rigidoporus lignosus: a Fourier transform infrared spectroscopic study, Biochim. Biophys. Acta., 1601: 155-162.

[6] Palmieri, G., P. Giardina, C. Bianco, A. Scaloni, A. Capasso and G. Sannia, (1997), A Novel White Laccase from Pleurotus ostreatus, J. Biol. Chem., 272(50): 31301-31307.

[7] Leontievsky, A. A., T. Vares, P. Lankinen, J. K. Shergill, N. N. Pozdnyakova, N. M. Myasoedova, N. Kalkinnen, L. A. Golovleva, R. Cammack, C. F. Thurston, and A. Hatakka (1997), Blue and yellow laccases of ligninolytic fungi, FEMS Microbiol. Lett., 156: 9-14.

[8] Arora DS, Sharma RK, (2010), Ligninolytic Fungal Laccases and Their Biotechnological Applications, Appl Biochem Biotechnol., 160: 1760-1788

[9] Claus, H., (2003), Laccases and their occurrence in prokaryotes, Arch microbial., 179: 145- 150

[10] Shekher, R., Sehgal, S., Kamthania, M., and Kumar, A., (2011), "Laccase: Microbial sources, production, purification, and potential biotechnological applications," Enzyme research, (1): 1-11. DOI: 10.4061/2011/217861

[11] Givaudan, A., Effosse, A., Faure, D., Potier, P., Bouillant, M.L. and Bally, R., (1993), Polyphenol oxidase in Azospirillum lipoferum isolated from rice rhizosphere: Evidence for laccase activity in nonmotile strains of Azospirillum lipoferum, FEMS Microbiol. Lett., 108: 205-210. https://doi.org/10.1111/j.1574-6968.1993.tb06100.x

[12] Sharma, P., Goel, R. and Caplash, N., (2007), Bacterial laccases, World J. Microbiol. Biotechnol., 23: 823832. https://doi.org/10.1007/s11274-006-9305-3

[13] Sharma, K.K. and Kuhad, R.C., (2008), Laccase: Enzyme revisited and function redefined, Ind. J. Microbiol., 48: 309316. https://doi.org/10.1007/s12088-008-0028-z

[14] Faure, D., Bouillant, M.L. and Bally, R., (1994), Isolation of Azospirillum lipoferum 4T Tn5 mutants affected in melanization and laccase activity, Appl. Environ. Microbiol., 60: 3413-3415. https://doi.org/10.1128/AEM.60.9.34133415.1994

[15] Faure, D., Bouillant, M. and Bally, R., (1995), Comparative study of substrates and inhibitors of Azospirillum lipoferum and Pyricularia oryzae laccases, Appl. Environ. Microbiol., 61:11441146. https://doi.org/10.1128/AEM.61.3.1144-1146.1995

[16] Alexandre G, Bally R, Taylor BL, Zhulin IB., (1999), Loss of cytochrome oxidase activity and acquisition of resistance to quinine analogs in a laccase-positive variant of Azospirillum lipoferum. J. Bacteriol., 181: 6730-6738.

[17] Alexandre, G., and Zhulin, I.B., (2000), Laccases are wide spread in bacteria. Trends Biotech., 18:4142. https://doi.org/10.1016/S0167-7799(99)01406-7

[18] Enguita, F.J., Martins, L.O., Henriques, A.O. and Carrondo, M.A., (2003), Crystal structure of a bacterial endospore coat component: A laccase with enhanced thermostability properties, J. Biol. Chem., 278: 1941619425. https://doi.org/10.1074/jbc.M301251200

[19] Galai S., Lucas-Elio P., Marzouki M. N., Sanchez-Amat A., (2011), Molecular cloning of a copper-dependent laccase from the dye-decolorizing strain Stenotrophomonas maltophilia AAP56, J. Appl. Microbiol., 111: 1394-1405. 10.1111/j.1365-2672.2011.05164.x

[20] Amat, A.S., Elio, P.L., Fernandez, E., Borron, J.C.G. and Solano, F., (2001), Molecular cloning and functional characterization of a unique multipotent polyphenol oxidase from Marinomonas mediterranea, Biochem. Biophys. Acta, 1547: 104-116. https://doi. org/10.1016/S0167-4838(01)00174-1

[21] Revankar MS, Lele SS, (2006), Enhanced production of laccase using a new isolate of white rot fungus WR-1, Process Biochem., 41:581-588. doi:10.1016/j.procbio.2005.07.019

[22] ,Aisemberg, G.O., Groteword, E., Taccioli G. E., and Judewicz, N. D., (1989), A major transcript in the response of Neurospora crassa to protein synthesis inhibition by cycloheximide, Exp. Mycol.,13: 121-128.

[23] Sadhasivam S, Savitha S, Swaminathan K, Lin FH, (2008), Production, purification and characterization of mid-redox potential laccase from a newly isolated Trichoderma harzianum WL1, Process Biochem., 43:736-742. doi:10.1016/j.procbio.2008.02.017

[24] Kiiskinen, L.L., K. Kruus, M. Bailey, E. Ylosmaki, M. Siika-Aho and M. Saloheimo, (2004), Expression of Melanospora albomyces laccase in Trichoderma reesei and characterization of enzyme, Microbiology, 150: 3065-3074.

[25] Olga Morozova, G. P. Shumakovich, S. V. Shleev, Ya. I. Yaropolov, (2007), Laccase-mediator systems and their applications: A review, Applied Biochemistry and Microbiology, 43(5):523-535. DOI:10.1134/S0003683807050055 


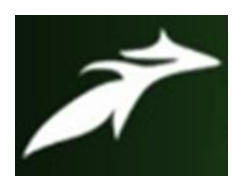

Amit Rastogi et al, International Journal of Advances in Agricultural Science \& Technology, Vol.8 Issue.12, December-2021, pg. 39-74

ISSN: 2348-1358

Impact Factor: 6.057

NAAS Rating: 3.77

[26] Liers C., Ullrich R., Pecyna M., Schlosser D., Hofrichter M., (2007), Production, purification and partial enzymatic and molecular characterization of a laccase from the wood-rotting ascomycete Xylaria polymorpha, Enzyme Microb. Technol., 41:785-793.

[27] Bailey, M. R., Woodard, S. L., Callaway, E., Beifuss, K., Magallanes-Lundback, M., Lane, J. R., (2004), Improved recovery of active recombinant laccase from maize seed. Appl. Microbiol. Biotechnol., 63: 390-397. doi:10.1007/s00253-003-1362-z

[28] Dittmer NT, Suderman RJ, Jiang H, Zhu Y-C, Gorman MJ, Kramer KJ, Kanost MR., (2004), Characterization of cDNAs encoding putative laccase-like multicopper oxidases and developmental expression in the tobacco hornworm, Manduca sexta, and the malaria mosquito, Anopheles gambiae, Insect Biochem. and Mol. Biol., 34:29-41.

[29] Arakane Y, Muthukrishnan S, Beeman RW, Kanost MR, Kramer KJ., (2005), Laccase 2 is the phenoloxidase gene required for beetle cuticle tanning, Proc. Natl. Acad. Sci. U.S.A., 102:11337-11342.

[30] Thurston CF, (1994), The structure and function of fungal laccases, Microbiology, 140:19-26.

[31] Liliana Quintanar, Jungjoo Yoon, Constantino P. Aznar, Amy E. Palmer, K. Kristoffer Andersson, R. David Britt and Edward I. Solomon, (2005), Spectroscopic and Electronic Structure Studies of the Trinuclear Cu Cluster Active Site of the Multicopper Oxidase Laccase: Nature of Its Coordination Unsaturation, J. Am. Chem. Soc., 127 (40): 1383213845

[32] G. Zoppellaro, H.W. Huang, T. Sakurai, (2000), Kinetic studies on the reaction of the fully reduced laccase with dioxygen, Inorg. React. Mech., 2: 79-84

[33] Feng Xu, (1996), Oxidation of Phenols, Anilines, and Benzenethiols by Fungal Laccases: Correlation between Activity and Redox Potentials as Well as Halide Inhibition, Biochemistry, 35 (23): 7608-7614

[34] Bourbonnais, R., Paice, M. G., Reid, I. D., Lanthier, P., and Yaguchi, M., (1995), Lignin oxidation by laccase isozymes from Trametes versicolor and role of the mediator 2,2'-azinobis(3-ethylbenzthiazoline-6-sulfonate) in kraft lignin depolymerisation, Appl. Environ. Microbiol., 61: 1876-1880.

[35] Du, X., Li, J., Gellerstedt, G., Rencoret, J., Del Río, J. C., Martínez, A. T., (2013), Understanding pulp delignification by laccase-mediator systems through isolation and characterization of lignin-carbohydrate complexes, Biomacromolecules, 14: 3073-3080. doi:10.1021/bm4006936

[36] Kunamneni, A., Ballesteros, A., Plou, F. J., and Alcalde, M., (2007), "Fungal laccase - A versatile enzyme for biotechnological applications," Applied Microbiology: 233-245.

[37] Xiaoting Jin, Xiangyang Yu, Guangyan Zhu, Zuntao Zheng, Fayun Feng, and Zhiyong Zhang, (2016), Conditions Optimizing and Application of Laccase-mediator System (LMS) for the Laccase-catalyzed Pesticide Degradation, Sci Rep., 6: 35787.

[38] Galhaup C, Wagner H, Hinterstoisser B, (2002), Increased production of laccase by the wood-degrading basidiomycete Trametes pubescens, Enzyme Microb Technol., 30 (4) :529-536. doi: 10.1016/S0141-0229(01)00522-1.

[39] Font, X., P. Blanquez, N. Casas, M. Gibarrell, M. Sarra and G. Caminal, (2003), Mechanism of textile metal dye transformation by Trametes versicolor, Water Res., 38: 2166-2172.

[40] Tavares, A.P.M., M.A.Z. Coelho, J.A.P. Coutinho and A.M.R.B. Xavier, (2005), Laccase improvement in submerged condition-induced production and kinetic modeling. J. Chem. Technol. Biotechnol., 80: 669-676.

[41] Roriz MS, Osma JF, Teixeira JA, Rodríguez Couto S, (2009), Application of response surface methodological approach to optimise Reactive Black 5 decolouration by crude laccase from Trametes pubescens, J. Hazard. Mater,169: 691-696.

[42] Narayanan MP, Murugan S, Eva AS, Devina SU, Kalidass S., (2015), Application of immobilized laccase from Bacillus subtilis MTCC 2414 on decolourization of synthetic dyes, Res J. Microbiol., 10: 421-432. doi: 10.3923/jm.2015.421.432.

[43] Jhadav, A., Vamsi, K. K., Khairnar, Y., Boraste, A., Gupta, N., Trivedi, S., Patil, P., Gupta, G., Gupta, M., Mujapara, A. K., Joshi, B. and Mishra, D., (2009), Optimization of production and partial purification of laccase by Phanerochaete chrysosporium using submerged fermentation, Int. J. Microbiol. Res., 1(2): 09-12.

[44] D'Souza-Ticlo, D., Verma, A.K., Mathew, M. and Raghukumar, C., (2006), Effect of nutrient nitrogen on laccase production, its isozyme pattern and effluent decolorization by the fungus NIOCC \#2a, isolated from mangrove wood, Indian J. Mar. Sci., 35: 364-372.

[45] Tavares APM, Coelho MAZ, Coutinho JAP, Xavier AMR, B, (2005), Laccase improvement in submerged cultivation: Induced production and kinetic modelling, J. Chem. Technol. Biotechnol., 80: 669-676.

[46] Xavier, A.M.R.B., A.P.M. Tavares, R. Ferreira and F. Amado, (2007), Trametes versicolor growth and laccase induction with by-products of pulp and paper industry, Elect. J. Biotechnol., 10: 444-452.

[47] Galai S, Limam F, Marzouki N., (20090, A New Stenotrophomonas maltophilia strain producing laccase. use in decolorization of synthetics dyes, Appl Biochem Biotechnol., 158: 416-431. doi: 10.1007/s12010-008-8369-y.

[48] Cavallazzi, J., Kasuya, C.M., and Soares, M.A., (2005), Screening of inducers for laccase production by Lentinula edodes in liquid medium, Brazillian Journal of Microbiology, 36: 383-387

[49] Valeriano VS, Silva AMF, Santiago MF, Bara MTF, Garcia TA, (2009), Production of laccase by Pynoporus sanguineus using 2,5 - Xylidine and ethanol, Braz J Microbiol., 40: 790-794.

[50] Leštan, D., Leštan, M. and Perdih, A., (1994), Physiological aspects of Biosynthesis of Lignin Peroxidases by Phanerochaete chrysosporium, Appl. Environ. Microbiol., 60: 606-612.

[51] Rothschild, N., Hadar, Y. and Dosoretz, C., (1995), Ligninolytic System Formation by Phanerochaete chrysosporium in Air, Appl. Environ. Microbiol., 61: 1833-1838. 


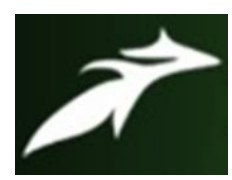

Amit Rastogi et al, International Journal of Advances in Agricultural Science \& Technology, Vol.8 Issue.12, December-2021, pg. 39-74

ISSN: 2348-1358

Impact Factor: 6.057

NAAS Rating: 3.77

[52] Dombrovskaya, E. N. and Kostyshin, S. S., (1996), Effects of surfactants of different ionic nature on the ligninolytic complexes of the white rot fungi Pleurotus floridae and Phellinus igniarius, Biochem. (Moscow)., 61: 215-219.

[53] Hess, J., Leitner, C., Galhaup, C., Kulbe, K.D., Hinterstoisser, B., Steinwender, M. and Haltrich, D., (2002), Enhanced formation of extracellular laccase activity by the white-rot fungus Trametes multicolor. Appl Biochem Biotech, 98: 229241.

[54] M. Mohorčič, J. Friedrich, and A. Pavko, (2004), "Decolourization of the diazo dye reactive black 5 by immobilised Bjerkundera adusta in a stirred tank bioreactor," Acta Chimica Slovenica, 51(4): 619-628.

[55] A. P. M. Tavares, M. A. Z. Coelho, M. S. M. Agapito, J. A. P. Coutinho, and A. M. R. B. Xavier, (2006), "Optimization and modeling of laccase production by Trametes versicolor in a bioreactor using statistical experimental design," Applied Biochemistry and Biotechnology, 134 (3): 233-248,

[56] Zhang, H., Hong, Y.Z., Xiao, Y.Z., Yuan, J., Tu, X.M., Zhang, X.Q., (2006), Efficient production of laccases by Trametes sp. AH28-2 in cocultivation with a Trichoderma strain, Appl. Microbiol. Biotechnol., 73: 89-94.

[57] Palmieri, G., Giardina, P., Bianco, C., Fontanella, B. and Sanni, G., (2000), Copper induction of laccase isozymes in the ligninolytic fungus Pleurotus ostreatus, Applied and Environmental Microbiology, 66: 920-924.

[58] Gorbacheva MA et al., (2009), Enzymatic oxidation of manganese ions catalysed by laccase, Bioorg. Chem., 37: 1-5

[59] Narayanan MP, Murugan S, Eva AS, Devina SU, Kalidass S., (2015), Application of immobilized laccase from Bacillus subtilis MTCC 2414 on decolourization of synthetic dyes, Res J Microbiol., 10: 421-432. doi: 10.3923/jm.2015.421.432.

[60] Safari Sinegani, A. A., Emtiazi, G., Hajrasuliha, S. and Shariatmadari, H., (2005), Biodegradation of some agricultural residues by fungi in agitated submerged cultures, African Journal of Biotechnology, 4 (10): 1058-1061.

[61] Narayanan MP, Murugan S, Eva AS, Devina SU, Kalidass S., (2015), Application of immobilized laccase from Bacillus subtilis MTCC 2414 on decolourization of synthetic dyes, Res J Microbiol., 10: 421-432. doi: 10.3923/jm.2015.421.432.

[62] Octavio, L.C., P.P.M.C. Irma, B.R.J. Ricardo and V.O. Francisco, (2006), Laccases. In: Advances in Agricultural and Food Biotechnology, Guevara-Gonzalez, R.G. and I. Torres-Pacheco (Eds.). Departamento de Ingenieria Bioquimica, Instituto Tecnologico de Celaya, Kerala, India, ISBN: 81-7736-269-0. pp: 323-340

[63] C.G. Ellen, RFH. Dekker, A.M. Barbosa, (2008), Orange bagasse as a substrate for the production of pectinase and laccase by Botryosphaeria rodhina MAMB-05 in submersed and SSF, Bioresources, 3:335-345.

[64] S. Kapoor, P.K. Khanna, and P. Katyal, (2009), Effect of suppliment of wheat straw on growth and lignocellulolytic enzyme potential of Lentinus edodes, W.J. Agric. Sci., 5: 328-381.

[65] Khammuang, S. and R. Sarnthima, (2009), Laccase activity from fresh fruiting bodies of Ganoderma sp. MK05: Purification and remazol brilliant blue R decolorization, J. Biol. Sci., 9: 83-87.

[66] Viswanath, B., M.S. Chandra, K.P. Kumar and B. Rajasekhar-Reddy, (2008), Production and purification of laccase from Stereum ostrea and its ability to decolorize textile dyes, Dyn. Biochem. Process Biotechnol. Mol. Biol., 2: 19-25.

[67] Yang, X.Q., X.X. Zhao, C.Y. Liu, Y. Zheng and S.J. Qian, (2009), Decolorization of azo, triphenylmethane and anthraquinone dyes by a newly isolated Trametes sp. SQ01 and its laccase, Process Biochem., 44: 1185-1189.

[68] Kiiskinen, L.L., K. Kruus, M. Bailey, E. Ylosmaki, M. Siika-Aho and M. Saloheimo, (2004), Expression of Melanocarpus albomyces laccase in Trichoderma reesei and characterization of the purified enzyme, Microbiology, 150: 3065-3074.

[69] Judewicz, N.D., Grotewold, E., Taccioli, G.E. and Aisemberg, G.O., (1998), "Purification of an extracellular fungal laccase", Mircen Journal of Applied Microbiology and Biotechnology, 4: 357-363.

[70] Han, M.J. and H.T. Choi and H.G. Song, (2005), Purification and characterization of laccase from the white rot fungus Trametes versicolor, J. Microbiol., 43: 555-560.

[71] Cordi L, Minussi RC, Freire RS, Durán N., (2007), Fungal laccase: copper induction, semi-purification, immobilization, phenolic effluent treatment and electrochemical measurement, Afr J Biotechnol., 6: 1255-1259.

[72] Minussi, R. C., Rossi, M., Bologna, L., Rotilio, D., Pastore, G. M., and Durán, N., (2007), Phen ols removal in musts: strategy for wine stabilization by laccase, J. Mol. Catal. B Enzym., 45: 102-107. doi: 10.1016/j.molcatb.2006.12.004

[73] Judewicz, N.D., E. Grotewold, G.E. Taccioli and G.O. Aisemberg, (1998), Purification of an extracellular fungal laccase, MIRCEN J., 4: 357-363.

[74] D'Souza-Ticlo, D., D. Sharma and C. Raghukumar, (2009), A thermostable metal-tolerant laccase with bioremediation potential from a marine-derived fungus, Mar. Biotechnol., 11: 725-737.

[75] Han, M.J., H.T. Choi and H.G. Song, (2005), Purification and characterization of laccase from the white rot fungus Trametes versicolor, J. Microbiol., 43: 555-560.

[76] Cordi L, Minussi RC, Freire RS, Durán N., (2007), Fungal laccase: copper induction, semi-purification, immobilization, phenolic effluent treatment and electrochemical measurement, Afr J Biotechnol., 6: 1255-1259.

[77] Dubé E, Shareck F, Hurtubise Y, Daneault C, Beauregard M, (2008), Homologous cloning, expression, and characterization of a laccase from Streptomyces coelicolor and enzymatic decolourisation of an indigo dye, Appl Microbiol Biotechnol, 79: 597-603.

[78] Valeriano VS, Silva AMF, Santiago MF, Bara MTF, Garcia TA, (2009), Production of laccase by Pynoporus sanguineus using 2,5 - Xylidine and ethanol, Braz J Microbiol, 40: 790-794.

[79] Kunamneni, A., Camarero, S., García-Burgos, C., Plou, F.J., Ballesteros, A. and Alcalde, M., (2008), Engineering and applications of fungal laccases for organic synthesis, Microb Cell Fact., 7, 32. doi: 10.1186/1475-2859-7-32 


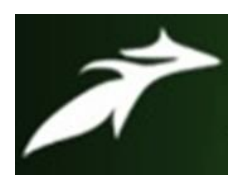

Amit Rastogi et al, International Journal of Advances in Agricultural Science \& Technology, Vol.8 Issue.12, December-2021, pg. 39-74

ISSN: 2348-1358

Impact Factor: 6.057

NAAS Rating: 3.77

[80] Li, A., Y. Zhu, L. Xu, W. Zhu and T. Xingjun, (2008), Comparative study on the determination of assay for laccase of Trametes sp., Afr. J. Biochem., 2: 181-183.

[81] Tzialla, A.A., A.A. Taha, E. Kalogeris and H. Stamatis, (2009), Improving the catalytic performance of fungal laccases in monoterpene-based reaction systems. Biotech. Lett., 31: 1451-1456.

[82] Valeriano, V.S., A.M.F. Silva, M.F. Santiago, M.T.F. Bara and A.G. Telma, (2009), Production of laccase By Pynocorpus sanguineus using 2,5- xylidine and ethanol, Braz. J. Microbiol., 40: 790-794.

[83] Mansur, M., M.E. Arias, J.L. Copa-Patino, M. Flardh and A.E. Gonzalez, (2003), The white-rot fungus Pleurotus ostreatus secretes laccase isozymes with different substrate specificities, Myc ologia, 95: 1013-1020.

[84] Wahleithner JA, Xu F, Brown KM, Brown SH, Golightly E, Halkier T, Kauppinen S, Pederson A, Schneider P, (1996), The identification and characterization of four laccases from the plant-pathogenic fungus Rhizoctonia solani, Curr. Genet., 29: 395-403.

[85] Kwon, S.-I. and Anderson, A.J., (2001), Laccase isozyme production by an opportunistic pathogen, a Fusarium proliferatum isolate from wheat, Physiol. Mol. Plant Pathol., 59: 235-242.

[86] Bertrand, T., C. Jolivalt, P. Briozzo, J. N. Caminade,C. Madzak and C. Mougin, (2002), Crystal structure of four-copper laccase complexed with an arylamide: insights into substrate recognition and correlation with kinetics, Biochem., 41: 7325-7333.

[87] Mohammadian M, Roudsari MF, Mollania N, Dalfard AB, Khajeh K., (2010), Enhanced expression of a recomninant bacterial laccase at low temperature and microacrobic conditions: purification and biochemical characterization, $J$ Ind Microbiol Biotechnol., 5: 41-45,

[88] Forgacsa, E., Cserhatia, T., Oros, G., (2004), Removal of synthetic dyes from wastewaters: a review. Environment International, 30: 953-97

[89] Wesenberg, D., Kyriakides, I. and Agathos, S.N., (2003), Whiterot fungi and their enzymes for the treatment of industrial dye effluents, Biotechnol Adv., 22: 161-187.

[90] Moilanen U, Osma JF, Winquist E, Leisola M, Couto SR., (2010), Decolorization of simulated textile dye baths by crude laccases from Trametes hirsute and Cerrena unicolor., Eng Life Sci., 10(3): 1-6.

[91] Vandevivere, P. C., Bianchi, R. and Verstraete, W., 1998, "Treatment and reuse of wastewater from the textile wetprocessing industry: review of emerging technologies", Journal of Chemical Technology and Biotechnology, 72: 289302.

[92] Khlifia R, Belbahria L, Woodwarda S, Ellouza M, Dhouiba A, Sayadia S, Mechichia T., (2010), Decolourization and detoxification of textile industry wastewater by the laccase-mediator system, J Hazard Mater. 175: 802-80.

[93] Banat IM, Nigam P, Singh D, Marchant R, (1996), Microbial decolorization of textile-dye-containing effluents: a review, Bioresource Technology, 58: 217- 227

[94] Cristovao RO, Tavares APM, Ribeiro A, Loureiro JM, Boaventura RAR, Macedo EA., (2008), Kinetic modelling and simulation of laccase catalyzed degradation of reactive textile dyes, BioresTechnol, 99: 4768-4774.

[95] Asghar M, Batool S, Bhatti HN, Noreen R, Rahman SU, Asad MJ., (2008), Laccase mediated decolorization of vat dyes by Coriolus versicolor IBL-04, Int Biodet Biodeg., 62: 465-470.

[96] Khlifia R, Belbahria L, Woodwarda S, Ellouza M, Dhouiba A, Sayadia S, Mechichia T., (2010), Decolourization and detoxification of textile industry wastewater by the laccase-mediator system, $J$ Hazard Mater., 175: 802-80.

[97] Moilanen U, Osma JF, Winquist E, Leisola M, Couto SR., (2010), Decolorization of simulated textile dye baths by crude laccases from Trametes hirsute and Cerrena unicolor., Eng Life Sci., 10(3): 1-6.

[98] Morozova OV, Shumakovich GP, Gorbacheva MA, Shleev SV, Yaropolov AI., (2007), "Blue" Laccases, J Biochem., 72(10): 1136-1150.

[99] Duran N and Esposito E., (2000), Potential applications of oxidative enzymes and phenoloxidase-like compounds in wastewater and soil treatment: a review. Appl Cataly Env., 28: 83-99.

[100]Rosana C, Minussi Y, Pastore GM, Durany N., (2002), Potential applications of laccase in the food industry, Trends in Food Sci Technol., 13: 205- 216.

[101]Cantarelli C, Brenna O, Giovanelli G, Rossi M., (1989), Beverage stabilization through enzymatic removal of phenolics. Food Biotechnol., 3: 203-214.

[102]Minussi RC, Pastore GM, Duran N., (2002), Potential applications of laccase in the food industry, Trends in Food Scien Technol., 13: 205-216.

[103]Burton S. (2003), Laccases and phenol oxidases in organic synthesis, Curr Org Chem., 7: 1317-1331.

[104]Pilz R, Hammer E, Schauer F, Krag U., (2003), Laccase catalyzed synthesis of coupling products of phenolic substrates in different reactors, Appl Microbiol Biotechnol., 60: 708-712.

[105] Kurisawa M, Chung JE, Uyama H, Kobayashi S., (2003), Laccase-catalyzed synthesis and antioxidant property of poly(catechin)., Macromol Biosci., 3: 758-764.

[106]Nicotra S, Cramarossa MR, Mucci A, Pagnoni UM, Riva S, Forti L., (2004), Biotransformation of resveratrol: synthesis of trans-dehydrodimers catalyzed by laccases from Myceliophtora thermophyla and from Trametes pubescens, Tetrahedron., 60: 595-600.

[107]Intra A, Nicotra S, Riva S, Daniel B., (2005), Significant and unexpected solvent influence on the selectivity of laccasecatalyzed coupling of tetrahydro-2-naphthol derivatives, Adv Synth Catal., 347: 973-977. 


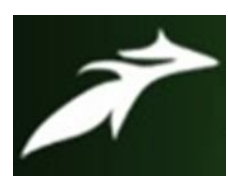

Amit Rastogi et al, International Journal of Advances in Agricultural Science \& Technology, Vol.8 Issue.12, December-2021, pg. 39-74

ISSN: 2348-1358

Impact Factor: 6.057

NAAS Rating: 3.77

[108]Ncanana S, Baratto L, Roncaglia L, Riva S, Burton SG., (2007), Laccase mediated oxidation of totarol. Adv Synth Catal., 349: 1507-1513.

[109]Shiba T, Xiao L, Miyakoshi T, Chen CL., (2000), Oxidation of isoeugenol and coniferyl alcohol catalyzed by laccase isolated from Rhus vernicifera Stokes and Pycnoporus coccineus. J Mol Catal Enzym. 10: 605-615.

[110]Monteiro MC \& de Carvalho MEA, (1998), Pulp bleaching using laccase from Trametes versicolor under high temperature and alkaline conditions, Appl Biochem Biotechnol., 70: 983-993.

[111]Bermek, H., Gu"lseren, I., Li, K., Jung, H. and Tamerler, C., (2004), The effect of fungal morphology on ligninolytic enzyme production by a recently isolated wood-degrading fungus Trichophyton rubrum LSK-27, World J Microbiol Biotechnol., 20: 345-349.

[112]Crestini, C., Argyropoulos, D.S., (1998), The early oxidative biodegradation steps of residual kraft lignin models with laccase, Biorg. Med. Chem., 6: 2161-2169.

[113]Calvo AM, Copa-Patiño JL, Alonso O, González AE, (1998), Studies of the production and characterization of laccase activity in the basidiomycete Coriolopsis gallica, an efficient decolorizer of alkaline effluents, Arch Microbiol., 171: 3136.

[114]Taspinar A, Kolankaya N, (1998), Optimization of enzymatic chlorine removal from kraft pulp, Bull Environ Contam Toxicol., 61: 15-21.

[115]Milstein, O., B. Nicklas and A. Huttermann, (1989), Oxidation of aromatic compounds in organic solvents with laccase from Trametes versicolor, Appl. Microbiol. Biotechnol., 31: 70-74.

[116]Buchanan, I.D., Nicell, J.A., (1997), Model development for horseradish peroxidase catalyzed removal of aqueous phenol, Biotechnol. Bioeng., 54: 251-261.

[117]Aktaş N, Şahiner N, Kantoğlu Ö, Salih B, Tanyolaç A, (2003), Biosynthesis and characterization of laccase catalyzed poly(catechol), J Polym Environ., 11(3):123-128

[118]Wu, Y. R., Luo, Z. H., Kwok-Kei Chow, R., and Vrijmoed, L. L., (2010), Purification and characterization of an extracellular laccase from the anthracene-degrading fungus Fusarium solani MAS2, Bioresour. Technol., 101: 97729777. doi: 10.1016/j.biortech.2010.07.091

[119]Kuznetsov BA, Shumakovich GP, Koroleva OV, Yaropolov AI., (2001), On applicability of laccase as label in the mediated and mediator less electroimmuno assay: effect of distance on the direct electron transfer between laccase and electrode, Biosens Bioelectron, 16(1-2): 73-84. doi: 10.1016/S0956-5663(00)00135-4.

[120]Ghindilis Al, Gavrilova VP, Yaropolov AI, (1992), Laccase based biosensor for determination of polyphenols: determination of cathecols in tea, Biosens Bioelectronics, 7: 127 \pm 131

[121]Tayhas, G., Palmore, R., Kim, H.H., (1999), Electro-enzymatic reduction of dioxygen to water in the cathode compartment of a biofuel cell, J Electroanal Chem, 565: 110-117.

[122]Milstein, O., B. Nicklas and A. Huttermann, (1989), Oxidation of aromatic compounds in organic solvents with laccase from Trametes versicolor, Appl. Microbiol. Biotechnol., 31: 70-74.

[123]Mayer A.M. and Staples R.C., (2002), Laccase: new functions for an old enzyme. Phytochemical., 60 (6): 551-565.

[124]S. Kobayashi, H. Higashimura, (2003), Oxidative polymerization of phenol revisited, Prog polym. Sci. 28: 1015-1048.

[125]Mita, N., Tawaki, S.-I., Uyama, H., and Kobayashi, S., (2003), Laccase-catalyzed oxidative polymerization of phenols, Macromol. Biosci., 3: 253-257. doi: 10.1002/mabi.200390032

[126]Ikeda, R., H. Tanaka, H. Oyabu, H. Uyama and S. Kobayashi, (2001), Preparation of artificial urushi via an environmentally benign process, Bull. Chem. Soc. Jpn., 74: 1067-1073.

[127]Ikeda, R., Tanaka, H., Uyama, H., and Kobayashi, S., (1998), Laccase-catalyzed polymerization of acrylamide, Macromol. Rapid Commun. 19: 423-425. doi: 10.1002/(SICI)1521-3927(19980801)19:8<423::AIDMARC423>3.0.CO;2-K

[128]Budolfsen, G., Jensen, M.T., Heldt-Hansen, H.P., Stringer, M.A., Lange, L., (2004): WO04032648A1

[129]Aktas, N.; Tanyolac, A., (2003), Kinetics of laccase-catalyzed oxidative polymerization of catechol, J. Mol. Catal. B Enzym., 22: 61-69.

[130]Karamyshev, A. V., Shleev, S. V., Koroleva, O. V., Yaropolov, A. I., and Sakharov, I. Y., (2003), Laccase-catalyzed synthesis of conducting polyaniline, Enzyme Microb. Technol., 33: 556-564. doi: 10.1016/S0141-0229(03)00163-7

[131]S. Larsson, P. Cassland, L.J. Jönsson, (2001), Development of a Saccharomyces cerevisiae strain with enhanced resistance to phenolic fermentation inhibitors in lignocellulose hydrolysates by heterologous expression of laccase, Appl Environ Microbiol, 67: 1163-1170

[132]Schoevaart, R., Van Langen, L.M., Van Den Dool, R.T.M., Boumans, J.W.L., (2006), Methods for the preparation of cross-linked enzyme aggregates with improved properties, WO Patent 2006046865.

[133]Palonen H, Viikari L, (2004), Role of oxidative enzymatic treatments on enzymatic hydrolysis of softwood, Biotechnol Bioeng., 86(5): 550-557.

[134]Al. Cañas, S. Camarero, (2010), Laccases and their natural mediators: biotechnological tools for sustainable eco-friendly processes, Biotechnol. Adv. [epub ahead of print] 10.1016/j.biotechadv.2010.05.002

[135]Kimura, T., (2006): JP2006262728 A2

[136]An ES, Kim SC, Kim YH, Park SY, Ryu JY, Song BK, Song JK, ( 2005), Production of phenolic polymers using biocatalysts for polymerization, Patent KR2005011958A.

[137]Takahara J, (2004), Enzymic manufacture of polyphenylene oxide (PPO), Patent JP2004313057 A2. 


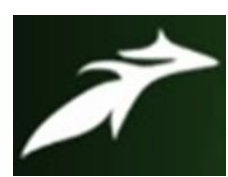

Amit Rastogi et al, International Journal of Advances in Agricultural Science \& Technology, Vol.8 Issue.12, December-2021, pg. 39-74

ISSN: 2348-1358

Impact Factor: 6.057

NAAS Rating: 3.77

[138]Schouten A, Wagemakers L, Stefanato FL, van der Kaaij RM, van Kan JAL., (2002), Resveratrol acts as a natural profungicide and induces self-intoxication by a specific laccase, Mol Microbiol., 43: 883-894.

[139]Tukayi Kudanga, Blessing Nemadziva, Marilize Le Roes-Hill, (2017), Laccase catalysis for the synthesis of bioactive compounds, Appl Microbiol Biotechnol., 101(1): 13-33. doi: 10.1007/s00253-016-7987-5.

[140]Torres E, Bustos-Jaimes I, Le Borgne S., (2003), Potential use of oxidative enzymes for the detoxification of organic pollutants, Applied Catalysis B: Environmental, 46: 1-15. doi: 10.1016/S0926-3373(03)00228-5.

[141]Pozdnyakova NN, Rodakiewicz-Nowak J, Turkovskaya OV, (2004), Catalytic properties of yellow laccase from Pleurotus ostreatus D1., J Mol Catal B Enzym, 30(1): 19-24.

[142]Pointing, S.B., (2001), Feasibility of bioremediation by white-rot fungi. Applied Microbiol. Biotechnol., 57: 20-33.

[143]D.C. Bressler, P.M. Fedorak, M.A., (2000), Pickard Oxidation of carbazole, N-ethylcarbazole, fluorene, and dibenzothiophene by the laccase of Coriolopsis gallica, Biotechnol. Lett., 22: 1119-1125.

[144]Dec, J., Bollag, J.-M., (2000), Phenoloxidase-mediated interactions of phenols and anilines with humic materials, Journal of Environmental Quality, 29: 665-676.

[145] Niku-Paavola, M.L. and L. Viikari, (2000), Enzymatic oxidation of alkenes, J. Mol. Cat. B: Enz., 10: 435-444.

[146]Bollag, J.-M., (1992), Decontaminating soil with enzymes: an in situ method using phenolic and anilinic compounds, Environmental Science and Technology, 26: 1876-1881

[147]Ahn, M.Y., J. Dec, J.E. Kim and J.M. Bollag, (2002), Treatment of 2,4-dichlorophenol polluted soil with free and immobilized laccase, J. Environ. Qual., 31: 1509-1515.

[148]Gelo-Pujic M, Hyug-Han Kim, Butlin N G, Tayhas G and Palmore R, (1999), Applied and environmental microbiology, 65(12): 5515.

[149]RIU, J.; SCHÖNSEE, I. and BARCELÓ, D., (1998), Determination of sulfonated azo dyes in groundwater and industrial effluents by automated solid-phase extraction followed by capillary electrophoresis-mass spectrometry, Journal of Mass Spectrometry, 33 (7): 653-663.

[150]Banat IM, Nigam P, Singh D, Marchant R, (1996), Microbial decolorization of textile-dye-containing effluents: a review, Bioresource Technol., 58: 217-227.

[151]Zollinger, H., (2002), Synthesis, Properties and Applications of Organic Dyes and Pigments, In: Colour Chemistry, Zollinger, H. (Ed.). John Wiley-VCH Publishers, New York: 92-100.

[152]Poots VJP, McKay G, Healy JJ, (1976), The removal of acid from effluent using natural adsorbents, I. Peat. Water Res., 10(12): 1061-1066.

[153]McKay, G., (1979), 'Waste colour removal from textile effluents', American Dyestuff. Rep.,68: 29 - 36.

[154] H. Hou, J. Zhou, J. Wang, C. Du, B. Yan, (2004), Enhancement of laccase production by Pleurotus ostreatus and its use Process, Biochem., 39: 1415-1419.

[155]Couto, S.R. and J.L.T. Herrera, (2006), Industrial and biotechnological applications of laccases: A review, Biotechnol. Adv., 24: 500-513.

[156]Setti, L., Giuliani, S., Spinozzi, G. and Pifferi, P.G., (1999), Laccase catalyzedoxidative coupling of 3-methyl 2benzothiazolinone hydrazone and methoxyphenols, Enzyme Microb. Technol., 25: 285289. https://doi.org/10.1016/S0141-0229(99)00059-9

[157]Raghukumar, C., (2000), Fungi from marine habitats: an application in bioremediation, Mycol. Res., 104: 1222-1226.

[158] Soares, G.M.B., M.T. Pessoa de Amorim, M. Costa-Ferreira, (2001), Use of laccase together with redox mediators to decolourize Remazol brilliant blue, R. J. Biotechnol., 89: 123-129.

[159]Abadulla E, Tzanov T, Costa S, Robra KH, Cavaco-Paulo A, Gübitz GM, (2000), Decolorization and detoxification of textile dyes with a laccase from Trametes hirsute, Appl Environ Microbiol., 66: 3357-3362.

[160]E. Rodriguez, M.A. Pickard, R. Vazquez-Duhalt, (1999), Industrial dye decolorization by laccases from lignolytic fungi, Curr. Microbiol., 38: 27-32.

[161]Yaver DS, Xu F, Golightly EJ, Brown KM, Brown SH, Rey MW, Schneider P, Halkier T, Mondorf K, Dalbøge H., (1996), Purification, characterization, molecular cloning and expression of two laccase genes from the white rot basidiomycete Trametes villosa, Applied and Environmental Microbiology, 62: 834 - 841.

[162]R.G. Saratale, G.D. Saratale, J.S. Chang, S.P. Govindwar, (2010), Decolorization and biodegradation of reactive dyes and dye wastewater by a developed bacterial consortium, Biodegradation, 21 (6): 999-1015

[163]D'Annibale, A., Stazi, S.R., Vinciguerra, V. et al., (2000), Oxirane-immobilized Lentinula edodes laccase: stability and phenolics removal efficiency in olive mill wastewater, Journal of Biotechnology, 77: 265-273.

[164]Ying, G.-G., Williams, B. \& Kookana, R., (2002), Environmental fate of alkylphenols and alkylphenol ethoxylates - a review, Environ Int., 28: 215-226.

[165]Heemken, O. P., Reincke, H., Stachel, B. \& Theobald, N., (2001), The occurence of xenoestrogens in the Elbe river and the North Sea, Chemosphere, 45: 249-259.

[166] Soares, G.M.B., M.T. Pessoa de Amorim, M. Costa-Ferreira, (2001), Use of laccase together with redox mediators to decolourize Remazol brilliant blue, R. J. Biotechnol., 89: 123-129.

[167]Lyons JI, Newell SY, Buchan A, Moran MA, (2003), Diversity of ascomycete laccase gene sequences in a Southeastern US salt marsh, Microb Ecol., 45: 270 - 281. 


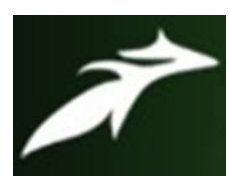

Amit Rastogi et al, International Journal of Advances in Agricultural Science \& Technology, Vol.8 Issue.12, December-2021, pg. 39-74

ISSN: 2348-1358

Impact Factor: 6.057

NAAS Rating: 3.77

[168]Calvo AM, Copa-Patiño JL, Alonso O, González AE, (1998), Studies of the production and characterization of laccase activity in the basidiomycete Coriolopsis gallica, an efficient decolorizer of alkaline effluents, Arch Microbiol., 171: 3136.

[169]Bassanini, I.; Ferrandi, E.E.; Riva, S.; Monti, D., (2021), Biocatalysis with Laccases: An Updated Overview. Catalysts, 11:26. https://doi.org/10.3390/ catal11010026

[170]Rakesh R.Nair, PhilippeDemarche, Spiros N.Agathos, (2013), Formulation and characterization of an immobilized laccase biocatalyst and its application to eliminate organic micropollutants in wastewater, New Biotechnology, 30(6): 814-18.

[171]Diana M. Mate and Miguel Alcalde, (2017), Laccase: a multi-purpose biocatalyst at the forefront of biotechnology, Microb Biotechnol., 10(6): 1457-1467.

[172]Brink, L.E.S., Tramper, J., Luyben, K.Ch.A.M. \& van't Riet, K., (1988), Biocatalysis in organic media, Enz. Micr. Technol., 10: 736743.

[173]Luterek, J., L. Gianfreda, M. Wojtas-Wasilewska, Nam-Seok Cho, J. Rogalski, M. Jaszek, E. Malarczyk, M. Staszczak, M. Fink-Boots and A. Leonowicz, (1998), Activity of free and immobilized extracellular Cerrena unicolor laccase in water miscible organic solvents, Holzforschung, 52: 589-595.

[174]Rodakiewicz-Nowak J., Kasture S., Dudek B., Haber J., (2000), Effect of various water-miscible solvents on enzymatic activity of fungal laccases, J. Mol. Catal. B Enzym., 11: 1-11. 10.1016/S1381-1177(00)00183-1

[175]Xu, F., (1999), "Recent progress in laccase study: properties, enzymology, production, and applications," in Encyclopedia of Bioprocess Technology: Fermentation, Biocatalysis, Bioseparation, eds M. C. Flickinger and S. W. Drew (New York: John Wiley \& Sons, Inc.): 1545-1554.

[176]Durán N, Rosa MA, D’Annibale A, Gianfreda L, (2002), Applications of laccases and tyrosinases (phenoloxidases) immobilized on different supports: A review, Enzyme Microb. Technol., 31: 907-931.

[177]Felipe de Salas, Pablo Aza, Joan F. Gilabert, Gerard Santiago, Sibel Kilic, Mehmet E. Sener, Jesper Vind, Víctor Guallar, Angel T. Martínez and Susana Camarero , (2019), Engineering of a fungal laccase to develop a robust, versatile and highly-expressed biocatalyst for sustainable chemistry, Green Chem., 21: 5374-5385.

[178]N. Durán, E. Esposito, (2000), Potential applications of oxidative enzymes and phonoloxidase-like compounds in wastewater and soil treatment: a review, Appl Catal B: Environ, 28: 83-99

[179]Mai C, Schormann W, Milstein O, Hüttermann A, (2000), Enhanced stability of laccase in the presence of phenolic compounds, Appl Microbiol Biotechnol , 54(4): 510-514.

[180]Nyanhongo GS, Gomes J, Gubitz G, Zvauya R, Read JS, Steiner W, (2002), Production of laccase by a newly isolated strain of Trametes modesta, Bioresour. Technol., 84: 259-263.

[181]Mustafa, R., L. Muniglia, B. Rovel and M. Girardin, (2005), Phenolic colorants obtained by enzymatic synthesis using a fungal laccase in hydro-organic biphasic system, Food Res. Int., 38: 995-1000.

[182]Semenov, A.N. et al., (1993), Peroxidase and laccase as catalysts for removal of the phenylhydrazide protecting group under mild conditions, Biotechnol. Bioeng., 42: 1137-1141.

[183]Uyama, H., and Kobayashi, S., (2002), Enzyme-catalyzed polymerization to functional polymers, J Mol Catal B Enzym., 19: $117-127$.

[184] Kurisawa, M., Chung, J.E., Uyama, H., and Kobayashi, S., (2003), Enzymatic synthesis and antioxidant properties of poly(rutin), Biomacromolecules, 4: 1394- 1399.

[185]Nicotra, S., M.R. Cramarossa, A. Mucci, U.M. Pagnoni, S. Riva and L. Forti, (2004), Biotransformation of resveratrol: Synthesis of trans-dehydrodimers catalyzed by laccases from Myceliophtora thermophyla and from Trametes pubescens, Tetrahedron, 60: 595-600.

[186]Roure, M.; Delattre, P.; Froger, H., (1992), Composition for an enzymic coloration of keratin fibres, especially for hair and its use in a dyeing process, Eur Pat Appl EP0504005.

[187]Aaslyng D, Sørensen N H, Rørbæk K, (1999), Novo Nordisk A/S, Patent US5948121.

[188]Lang G, Cotteret J, (22.07.1999), Hair dye composition containing a laccase. (L'Oreal, Fr.), Int Pat Appl WO9936036.

[189]Golz-Berner, K. , Walzel, B. , Zastrow, L. and Doucet, O, (2004), Cosmetic or dermatological preparation with skin-lightening proteins, WO2004017931A1.

[190]N. Enayatizamir, F. Tabandeh, S. RodríguezCouto, B. Yakhchali, H.A. Alikhani, L. Mohammadi, (2011), Biodegradation pathway and detoxification of the diazo dye reactive black 5 by Phanerochaete chrysosporium, Bioresource Technology, 102(22): 10359-10362.

[191]Rita de Cássia M. de Miranda , Edelvio de Barros Gomes , Nei Pereira Jr. , Maria Aparecida Marin-Morales , Katia Maria Gomes Machado , Norma Buarque de Gusmão, (2013), Biotreatment of textile effluent in static bioreactor by Curvularia lunata URM 6179 and Phanerochaete chrysosporium URM 6181, Bioresource Technology, 142: 361-367.

[192]Hakulinen N, Rouvinen J., (2015), Three-dimensional structures of laccases. Cell Mol Life Sci., 72: 857-868. doi: 10.1007/s00018-014-1827-5.

[193]Deepti Singh, Neeraj Gupta, (2020), Microbial Laccase: a robust enzyme and its industrial applications, Biologia, 75: 1183-1193

[194]Prakram Singh Chauhan, Bindi Goradia, Arunika Saxena, (2017), Bacterial laccase: recent update on production, properties and industrial applications, 3 Biotech, 7(5): 1-20. DOI 10.1007/s13205-017-0955-7 


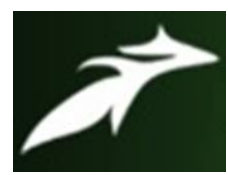

Amit Rastogi et al, International Journal of Advances in Agricultural Science \& Technology, Vol.8 Issue.12, December-2021, pg. 39-74

ISSN: 2348-1358

Impact Factor: 6.057

NAAS Rating: 3.77

[195]Guan ZB, Shui Y, Song CM, Zhang N, Cai YJ, Liao XR, (2015), Efficient secretory production of CotA-laccase and its application in the decolorization and detoxification of industrial textile wastewater, Environ Sci Pollut Res Int., 22(12): 9515-23.

[196]Shraddha, Ravi Shekher, Simran Sehgal, Mohit Kamthania, and Ajay Kumar, (2011), Laccase: Microbial Sources, Production, Purification, and Potential Biotechnological Applications, Enzyme Research, Article ID 217861: 1-11. doi:10.4061/2011/217861

[197]Pooja Upadhyay, Rahul Shrivastava and Pavan Kumar Agrawal,(2016), Bioprospecting and biotechnological applications of fungal laccase, 3 Biotech, 6(15): 1-12 DOI 10.1007/s13205-015-0316-3

[198]Shraddha, Ravi Shekher, Simran Sehgal, Mohit Kamthania, and Ajay Kumar, (2011), Laccase: Microbial Sources, Production, Purification, and Potential Biotechnological Applications, Enzyme Research , Article ID 217861: 1-11 doi:10.4061/2011/217861

[199]Adarsh Kumar and Ram Chandra, (2020), Ligninolytic enzymes and its mechanisms for degradation of lignocellulosic waste in environment, Heliyon., 6 (2): 1-18. doi: 10.1016/j.heliyon.2020.e03170

[200]BrunoLellisCíntia, ZaniFávaro-PolonioJoão, AlencarPamphileJulio, CesarPolonio, (2019), Effects of textile dyes on health and the environment and bioremediation potential of living organisms, Biotechnology Research and Innovation, 3(2): $275-290$

[201]Rosana C.Minussi, MassimoRossi, LucianoBologna, DomenicoRotilio, Gláucia M.Pastore, NelsonDurán, (2007), Phenols removal in musts: Strategy for wine stabilization by laccase, Journal of Molecular Catalysis B: Enzymatic, 45 (3): $102-107$

[202]Johann F. Osma, Jose L. Toca-Herrera, and Susana Rodriguez-Couto, (2010), Uses of Laccases in the Food Industry, Enzyme Research , Article ID 918761: 1-8 doi:10.4061/2010/918761

[203]Adinarayana Kunamneni, Susana Camarero, Carlos García-Burgos, Francisco J Plou, Antonio Ballesteros and Miguel Alcalde, (2008), Engineering and Applications of fungal laccases for organic synthesis, Microbial Cell Factories, 7 (32): 1-17 doi:10.1186/1475-2859-7-32 